\title{
DOSES DE CÁLCIO E ACÚMULO DE NUTRIENTES EM PLANTAS DE ALFACE CULTIVADAS POR AEROPONIA
}

\author{
CRISTIANE PIERROTTE CARVALHO
}

Orientador: Prof. Dr. QUIRINO AUGUSTO CAMARGO CARMELLO

Dissertação apresentada à Escola Superior de Agricultura "Luiz de Queiroz", Universidade de São Paulo, para obtenção do título de Mestre em Agronomia, Área de Concentração: Solos e Nutrição de Plantas

P I R A C I C A B A

Estado de São Paulo - Brasil

Março - 2001 


\section{DOSES DE CÁlCIO E ACÚMULO DE NUTRIENTES EM PLANTAS DE ALFACE CULTIVADAS POR AEROPONIA}

Autora: Cristiane Pierrotte Carvalho

$\begin{array}{cccll}\text { p. } & \text { item } & \text { linha } & \text { onde se lê } & \text { leia-se } \\ 5 & 3.1 & 15 & \begin{array}{l}\text {..tipos de estruturas } \\ \text { comercialmente viáveis }\end{array} & \begin{array}{l}\text {..tipos de estruturas não } \\ \text { forem comercialmente } \\ \text { viáveis }\end{array} \\ 8 & 3.3 & 19 & \text { Faquim (1996) } & \text { Faquim et al (1996) } \\ 9 & 3.4 & 2 & \text {...Em cultivos aeropônicos } & \text {...Em cultivos hidropônicos }\end{array}$

$\begin{array}{llll}14 & 3.8 & 14 & \text { Grande parte das soluções }\end{array}$ nutritivas têm capacidade tampão

Grande parte das soluções nutritivas não têm capacidade tampão

$18 \quad 4.2$

2

....parcelas subsubdivididas

....parcelas subdivididas

22 Quadro $218 \quad$...Nitrato de cálcio $0,86 \mathrm{mmol} \mathrm{L}^{-1}$

....Nitrato de cálcio $0,43 \mathrm{mmol} \mathrm{L}^{-1}$ 
Dados Internacionais de Catalogação na Publicação (CIP)

DIVISĀO DE BIBLIOTECA E DOCUMENTAÇĀO - Campus "Luiz de Queiroz"/USP

\section{Carvalho, Cristiane Pierrotte}

Doses de cálcio e acúmulo de nutrientes em plantas de alface cultivadas por aeroponia / Cristiane Pierrotte Carvalho. - Piracicaba, 2001.

74 p. : il.

Dissertação (mestrado) - Escola Superior de Agricultura Luiz de Queiroz, 2001. Bibliografia.

1. Aeroponia 2. Alface 3. Balanço de nutriente 4. Cálcio 5. Delineamento de experimento 6. Dosagem 7. Sistema radicular 8 . Solução nutritiva I. Título

CDD 635.52

Permitida a cópia total ou parcial deste documento, desde que citada a fonte-O $O$ autor" 
A Deus por ter me dado força e coragem nos momentos dificeis, E por ter me presenteado com uma familia maravilhosa e especial

Agradeço

Aos melhores e queridos pais do mundo, Nicanor e Adélia As minhas melhores amigas e irmãs Priscila, Yeda Maria e Heloise

A minha querida avó linda Laura Aos maiores incentivadores, exemplos e espelhos de vida pessoal e profissional, meu avô Nicanor Carvalho, meu pai Nicanor de Carvalho Júnior, meus tios e padrinho Luiz Henrique e Arnaldo Carvalho,

Ofereço

A meu companheiro de todas as horas, sempre me encorajando a transpor mais um obstáculo, acreditando e confiando, me tornando capaz, por todo amor e paciência dedicados, a você meu querido esposo Marcelo,

Dedico 


\section{AGRADECIMENTOS}

Ao Prof. Dr. Quirino Augusto de Camargo Carmello pela orientação e apoio no decorrer do curso de mestrado.

Ao setor de Nutrição Mineral de Plantas do Departamento de Química da Escola Superior de Agricultura "Luiz de Queiroz"/ USP pelo apoio e infra-estrutura na realização deste trabalho,

Aos Dr. Pedro Roberto Furlani e Dra. Angela Maria Cangiani Furlani do IAC pela amizade, carinho, incentivo, e pela oportunidade de aprendizado profissional e pessoal dada a minha pessoa.

Aos Professores Dr. Antonio Roque Dechen e Dr. Francisco Antonio Monteiro pela amizade e incentivo.

À CAPES pela concessão da bolsa de mestrado.

Aos funcionários do Setor de Nutrição Mineral de Plantas da ESALQ/USP: Edinéia Cristina S. Mondoni, Lurdes A. Dário de Gonzáles, Lúcia Helena S. Pavan Forti, Nivanda Maria de Moura e Sueli Maria Amaral Campos Bovi, pela amizade e pelo grande auxílio prestado na realização das análises químicas.

Ao amigo Tiago Pires Marques, aluno de graduação e estagiário do Setor de Nutrição de Plantas do Departamento de Química da Escola Superior de Agricultura "Luiz de Queiroz"/ USP pelo apoio, amizade, e pela total ajuda no experimento.

Ao Dr. Válter Casarin pela amizade, e apoio no decorrer do curso de mestrado.

Ao doutorando Jonas Ruschel, pela ajuda na montagem da estrutura de aeroponia.

A amiga doutoranda Walcylene Lacerda pela amizade, pelo apoio nos momentos difíceis e pela ajuda no experimento.

A amiga mestranda Danielle Takahashi pela amizade, carinho e ajuda nas análises estatísticas.

Ao amigo e doutorando Waldssimiller Mattos pela ajuda nas análises químicas, e pelo apoio e amizade no decorrer do curso.

Aos amigos de curso da Pós- graduação, Antonio Carlos, Beth, Cristiano, Genelício, Jean, João de Deus, José Lavres, Juliano, Marcos Gama, Márcio, Michelle, Miriam, Raquel, Roberto Wagner, Pauletti e Simone, pela amizade, pelo apoio e carinho durante o curso de mestrado, e a minha querida amiga do curso de graduação Stefania. 


\section{SUMÁRIO}

Página

RESUMO

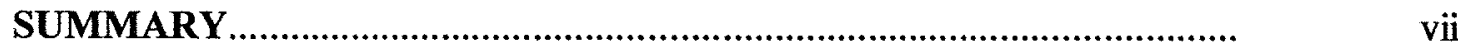

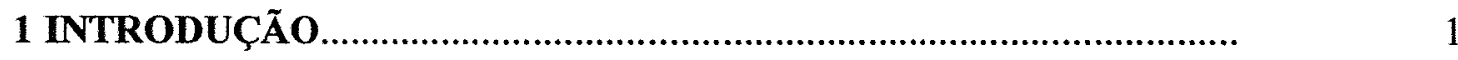

2 OBJETIVOS

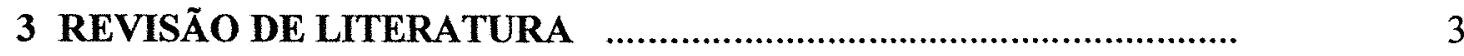

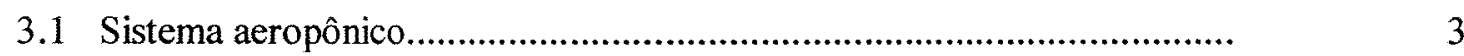

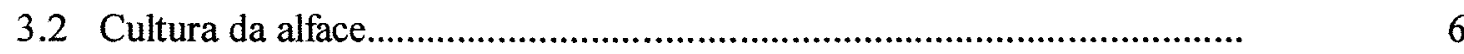

3.3 Propagação de plantas de alface para o cultivo hidropônico........................

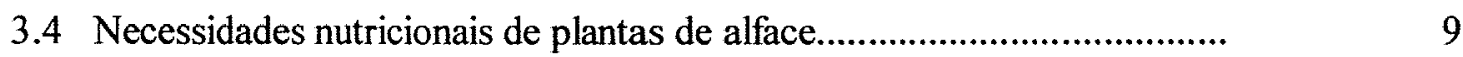

3.5 Deficiência de cálcio ou queima de bordos em alface........................... 10

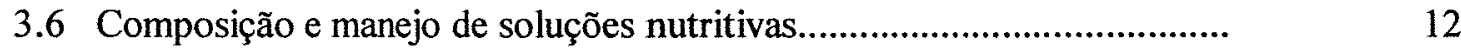

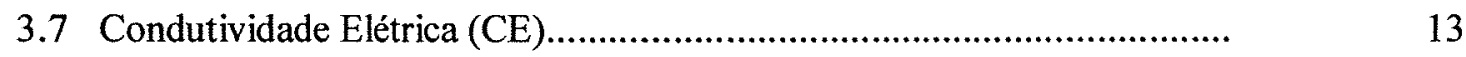

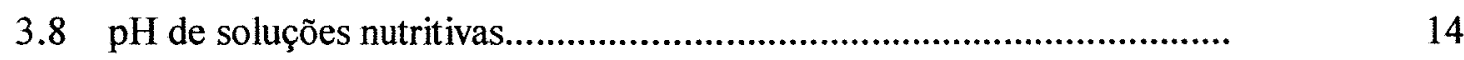

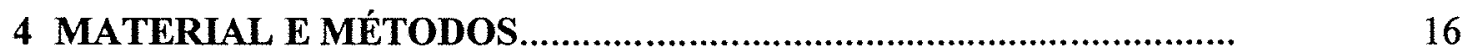

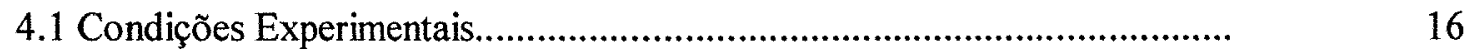

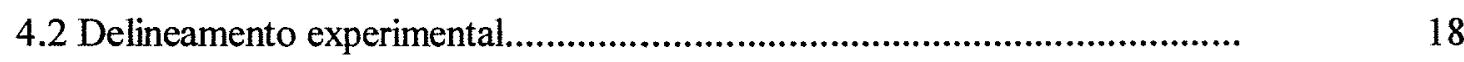

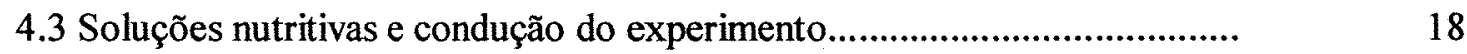

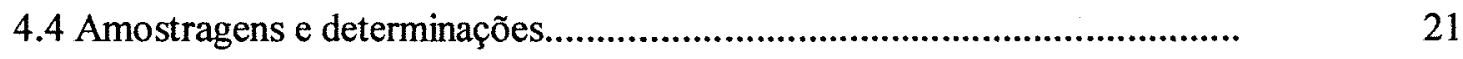

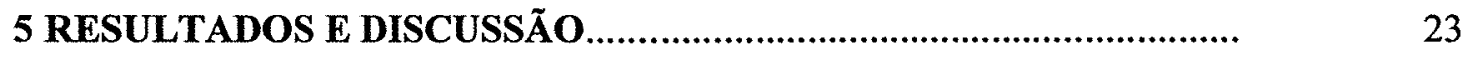

5.1 Acúmulo de material fresco e seco da parte aérea e raízes

Porcentagem material seco e Relação parte aérea/ raízes............................. 23 
5.2 Acúmulo de macronutrientes da parte aérea e raízes............................... 30

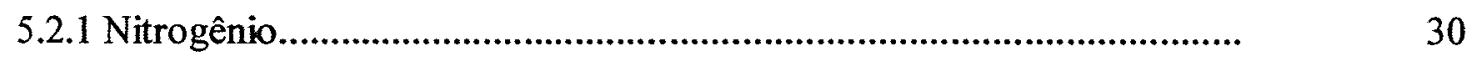

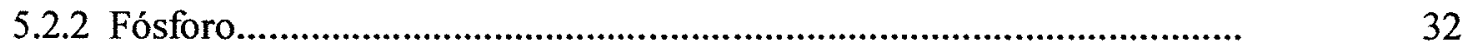

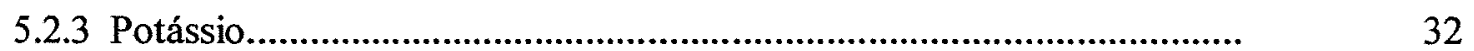

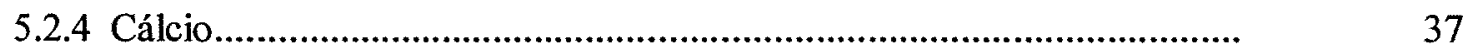

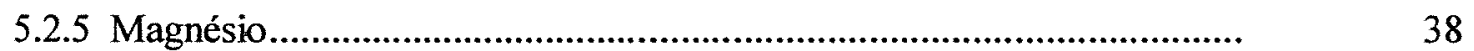

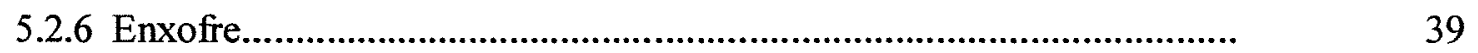

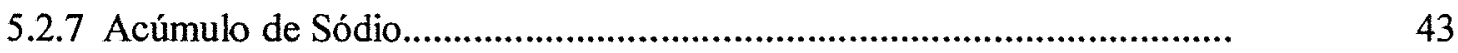

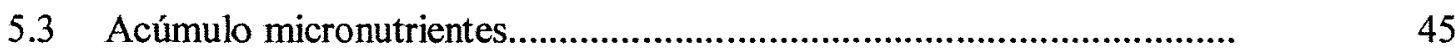

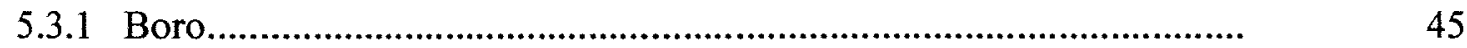

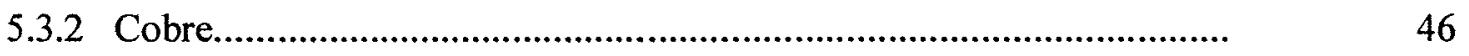

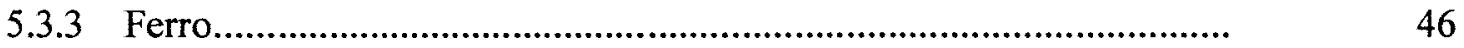

5.3.4 Manganês.............................................................................

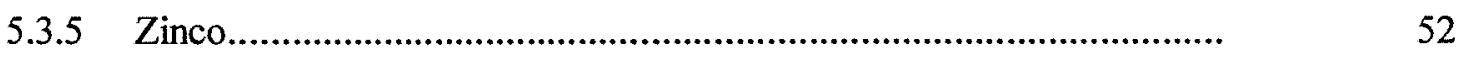

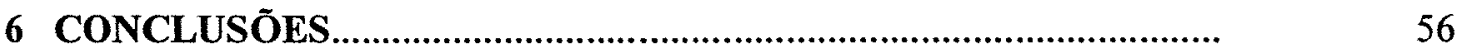

REFERÊNCIAS BIBLIOGRÁFICAS...............................................

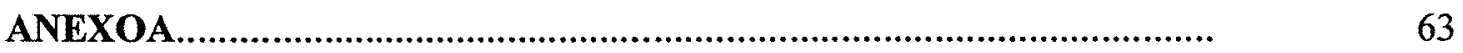

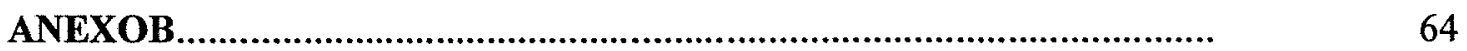




\title{
DOSES DE CÁlCIO E ACÚMULO DE NUTRIENTES EM PLANTAS DE ALFACE CULTIVADAS POR AEROPONIA
}

\author{
Autora: Cristiane Pierrotte Carvalho \\ Orientador: Prof. Dr. Quirino Augusto de C. Carmello
}

\section{RESUMO}

Aeroponia ou cultivo em névoa, é uma técnica de cultivo moderna, onde as plantas podem crescer adequadamente em colunas ou tubos verticais, se suas raízes estiverem suspensas em uma fina camada de solução, gerada pneumaticamente, ou de outra forma qualquer. A principal vantagem desse cultivo sobre os demais, é a facilidade com que o sistema radicular pode ser estudado, tendo porém a desvantagem de que, pequenas interrupções na produção de névoa, causada por problemas mecânicos, podem levar à danos nas raízes das plantas.

O objetivo deste trabalho foi avaliar o efeito de três concentrações de cálcio( 8,55 mmol $\mathrm{L}^{-1}, 5,70 \mathrm{mmol} \mathrm{L}^{-1}$ e $2,85 \mathrm{mmol} \mathrm{L}^{-1}$ ) e em diferentes posições nos tubos verticais no comportamento do cultivar de alface (Lactuca sativa L.) Vera cultivado no sistema de aeroponia, utilizando-se o delineamento experimental de parcelas subdivididas com quatro repetições.

Os resultados permitiram concluir que na solução nutritiva com menor dose de cálcio $\left(2,85 \mathrm{mmol} \mathrm{L}^{-1}\right)$, foram obtidos os maiores valores para a maioria das variáveis analisadas incluindo-se as produções de massa.

A posição superior das plantas nos tubos verticais do sistema de aeroponia resultou nos maiores valores de material fresco e seco e acúmulo de nutrientes, para a cultivar de alface Vera.

Não foi verificada a incidência de queima de bordos em folhas da cultivar testada, mesmo quando crescida com a menor dose de cálcio na solução nutritiva. 


\title{
CALCIUM LEVELS AND NUTRIENT ACCUMULATION IN LETTUCE PLANTS GROWN UNDER AEROPONIC
}

\author{
Author: Cristiane Pierrotte Carvalho \\ Adviser: Dr. Prof. Quirino Augusto de C. Carmello
}

\section{SUMMARY}

Aeroponics or cultivation under vapor is a modern cultivation technique, in which plants can grow properly in columns or vertical pipes, if their roots are suspended and involved by a thin layer of solution, pneumatically or otherwise produced. The main advantage of this kind of cultivation is the ease of studying the root system. However, the disadvantage of such a system is that short interruptions in the vapor production, due to mechanical failures, can harm the plant roots.

The aim of this study was to evaluate the effect of three calcium concentrations $(8,55$ mmol L ${ }^{-1}, 5,70 \mathrm{mmol} \mathrm{L}^{-1}$ and $2,85 \mathrm{mmol} \mathrm{L}^{-1}$ ), and the position on the vertical tubes on the behavior of lettuce (Lactuca sativa L.), cultivar Vera, under aeroponic conditions. An split plot design with four replicates was used.

Results showed that the nutrient solution containing the smallest amount of calcium, $2,85 \mathrm{mmol} \mathrm{L}^{-1}$, presented the greatest values for all variables analyzed, therefore yielding the best lettuce, Vera cultivar, production. The top position of the plants on vertical tubes under aeroponic conditions resulted in greatest values of the fresh and dry material and the accumulation of nutrients on the behavior of lettuce, cultivar Vera.

It was not verified any tipburn incidence on the lettuce plants, even when the smallest amount of calcium was employed in the nutritious solution. 


\section{INTRODUÇÃO}

O cultivo comercial de plantas em solução nutritiva pode ser feito, utilizando-se um meio sólido inerte e homogêneo (areia, silica, pedregulhos, serragem), um meio líquido estacionário (vasos) ou circulante (NFT), ou ainda, com as raízes suspensas em uma fina névoa de solução nutritiva (aeroponia).

A técnica do NFT já é utilizada por um grande número de pequenos e até grandes produtores de hortaliças, estando bastante difundida no Estado de São Paulo e, tendo os procedimentos de cultivo já bem dominados.

A aeroponia ou cultivo em névoa é uma técnica de cultivo moderna, onde as plantas podem crescer adequadamente, em colunas ou tubos verticais, se suas raízes estiverem suspensas em uma fina camada de solução, gerada pneumaticamente ou de outra forma qualquer. A principal vantagem desse cultivo, sobre os demais, é a facilidade com que o sistema radicular pode ser estudado, tendo porém como desvantagem, que pequenas interrupções na produção da névoa, causadas por problemas mecânicos, podem levar a danos nas raízes das plantas. Nesse método, normalmente, são fornecidas soluções nutritivas muito concentradas, em pequenos volumes na unidade de tempo.

A aeroponia teve sua introdução no nosso estado mais recentemente e, necessita um maior conhecimento e um maior investimento em instalações, o que tem feito poucos produtores tentarem produzir hortaliças utilizando essa técnica, a qual não está totalmente desenvolvida e dominada para as nossas condições. A principal vantagem dessa técnica é permitir a produção de um número bem maior de unidades de comercialização por área, o que deve compensar o custo maior das instalações.

A cultura da alface é de grande importância dentre as hortaliças cultivadas no Brasil, sendo mais usada na forma de saladas, na alimentação humana. Rica em vitaminas e sais minerais, é uma das melhores fontes de vitamina $A$, possuindo ainda as vitaminas $B_{1}, B_{2}$ e C. A alface é também uma das melhores fontes de cálcio, contendo também potássio, fósforo, sódio, magnésio e ferro . 


\section{OBJETIVOS}

Os objetivos deste trabalho foram avaliar o comportamento de plantas de alface da cultivar Vera cultivadas em solução nutritiva com diferentes concentrações de cálcio e em diferentes posições nos tubos verticais utilizados no sistema de aeroponia ou cultivo em névoa. 


\section{REVISÃO DE LITERATURA}

\subsection{Sistema aeropônico}

A aeroponia é largamente utilizada em pesquisas nos laboratórios de fisiologia vegetal e nutrição de plantas, mas não é tão comumente utilizada, como os outros métodos de cultivo sem solo, em escala comercial. Muitas companhias italianas estão, entretanto, utilizando aeroponia no cultivo de inúmeras espécies vegetais, tais como: alface, pepinos, melões e tomates (Jones Jr, 1983).

Para Jones Jr. (1983), os aspectos mais críticos dessa técnica são: a característica da névoa ou "spray", a frequiência de exposição das raízes à névoa e a composição da solução nutritiva.

Entre as vantagens oferecidas pela técnica do cultivo aeropônico sobre os outros sistemas de cultivo sem solo tradicionais estão: a maior área superficial dedicada ao cultivo, com um melhor aproveitamento da área disponivel do ambiente protegido, a melhoria das condições fitossanitárias, o maior nível de automação, o reduzido custo de produção e o maior número de ciclos de cultivo (Ardito, 1975; Massantini, 1973 e Vicenzoni, 1979).

O primeiro sistema aeropônico típico, foi descrito por Massantini (1973), na Itália. Posteriormente, Jensen e colaboradores, na Universidade do Arizona, desenvolveram um sistema similar, para o cultivo de alface, espinafre e tomates (Jensen, 1980).

Segundo Soffer \& Levinger (1980), foi desenvolvido no "kibutz" Ein Gedi, em Israel, uma tecnologia para a produção de tomates, pepinos e plantas ornamentais, utilizando-se a aeroponia. Ainda em Israel, em 1982, a empresa ADI Ltda., anunciou um sistema de aeroponia que estava sendo eficaz. O sistema era controlado por computador 
e permitia, através de sensores de umidade e de temperatura, uma perfeita regulagem do sistema, impossível de se obter em condições normais.

As produtividades obtidas com esse tipo de cultivo são muito superiores, porém o custo de implantação do sistema é alto, o que pode comprometer a viabilidade econômica do projeto.

Trabalhos inovadores com o cultivo aeropônico, continuam a ser feitos no Laboratório de Pesquisa Ambiental (ERL) da Universidade do Arizona, em Tucson. Trabalhando com a Walt Disney Productions, os doutores Carl Hodges, diretor do ERL e Merle Jensen, pesquisador em horticultura, desenvolveram conceitos para apresentar as tecnologias agrícolas de ponta ao público, de uma forma divertida. O ERL ajudou a criar duas das principais atrações do Epcot Center na Disney World, próximo a Orlando na Flórida: o cruzeiro de barco "Escutando a Terra" e o "tour Colheita de Amanhã", dentro do tema A Terra (Resh, 1995).

A Universidade de Purdue e o ERL ainda estão pesquisando sistemas de suporte de vida em ambientes controlados, para serem utilizados nas estações espaciais. Esses programas, patrocinados pela NASA, são chamados Sistemas de Suporte de Vida Ecologicamente Controlados (CELSS). O Laboratório de Pesquisa Ambiental da Universidade do Arizona está desenvolvendo sistemas de suporte para os visitantes que forem a Marte. Esses experimentos devem ser desenvolvidos em câmaras completamente fechadas. Sistemas fechados de hidroponia líquida devem ser utilizados, de forma que a solução excedente seja recuperada, completada e reciclada. Geralmente, isso é feito utilizando a técnica do fluxo laminar de solução (NFT) ou modificações dela (Resh, 1995).

Outros trabalhos realizados no ERL incluem o cultivo de alface em casas-devegetação, em estruturas de isopor em forma de um A. Nestes, as raizes crescem em direção ao centro da estrutura de isopor em $\mathrm{A}$, e são periodicamente pulverizadas com nutrientes. Esse sistema aeropônico aumentou o tamanho das cabeças de alface em relação às que poderiam crescer no espaço de uma casa-de-vegetação, de forma parecida com a dos sistemas "em cascata" ou em fluxo laminar de solução, o que diminuiu o custo 
unitário de produção. Por outro lado, os cientistas do ERL aumentaram a produção em casas-de-vegetação, cultivando melões em estruturas em A, enquanto os pés de alface eram cultivados em bandejas de isopor que flutuavam na solução abaixo dos melões (Resh, 1995).

Eles também cultivaram alfaces no interior de um cilindro largo que girava ao redor de uma fonte artificial de luz. A alface foi plantada através de buracos em um cilindro interno que girava a $50 \mathrm{rpm}$. Como o cilindro interno gira, as partes aéreas das plantas crescem em direção ao centro. As raízes, presas entre os dois cilindros, eram pulverizadas regularmente com nutrientes. O ERL também tem feito experiências com o sistema de esteiras condutoras de plantas penduradas em tubos verticais. As plantas suspensas nos tubos são periodicamente recicladas, passando pelos bicos pulverizadores, que aspergem os nutrientes no interior da parte superior dos tubos. Ao mesmo tempo, eles passam sobre um tanque aberto, de tal forma que o excesso de solução possa ser reciclado (Resh, 1995).

Enquanto esses tipos de estruturas comercialmente viáveis para cultivar tomates, pepinos ou melões, elas demonstram como, em aeroponia, pode-se cultivar plantas com sistemas radiculares grandes e saudáveis. Com o aumento do custo dos combustíveis para aquecer as casas-de-vegetação, novos sistemas de cultivos tais como NFT e a aeroponia podem ser adotados rapidamente no futuro, para economizar energia e aumentar os volumes de produção (Resh, 1995). 


\subsection{Cultura da alface}

A planta de alface (Lactuca sativa L.) pertence à familia Compositae, tribo Cichorieae, caracterizando-se pelo hábito herbáceo, devido ao caule muito curto, não ramificado, o que dá à planta um aspecto de roseta. As folhas, de forma arredondada, lanceolada ou quase espatulada, podem também encurvar-se e formar uma "cabeça", que é característica das variedades do tipo repolhuda. A consistência pode ser coreácea ou tenra. Os bordos dos limbos foliares podem ser lisos, ondulados ou crespos (Filgueira, 1982). O sistema radicular é pivotante, com ramificações finas e curtas que, segundo (Filgueira, 1982), exploram efetivamente de 15 a $30 \mathrm{~cm}$ de profundidade durante a fase vegetativa, que é a fase de interesse comercial.

A alface é uma alternativa alimentar de grande importância na alimentação e saúde humana, constituindo-se na mais popular dentre aquelas hortaliças em que as folhas são consumidas. Seu consumo é feito in natura e nessas condições ela apresenta a seguinte composição média por $100 \mathrm{~g}$ de massa de material fresco: água: $94 \%$; energia: $18 \mathrm{kcal}$; proteína: $1,3 \%$; gordura: $0,3 \%$; carboidratos totais: $3,5 \%$; fibra: $0,7 \%$; cálcio: $68 \mathrm{mg}$; fósforo: $27 \mathrm{mg}$; ferro: $1,4 \mathrm{mg}$; potássio: $264 \mathrm{mg}$; tiamina: $0,05 \mathrm{mg}$; riboflavina: $0,08 \mathrm{mg}$; niacina: $0,4 \mathrm{mg}$ e vitamina C: $18 \mathrm{mg}$ (Sgarbieri, 1987).

Já Oliveira \& Marchine (1998) separam por tipo, sendo que a alface do tipo folha crespa apresentava a seguinte composição média por $100 \mathrm{~g}$ de massa de material fresco: água: $94,8 \%$; energia: $13 \mathrm{kcal}$; proteína: $1,0 \mathrm{~g}$; gordura: $0,1 \mathrm{~g}$; carboidratos totais: $2,7 \mathrm{~g}$; fibra: $0,5 \mathrm{~g}$; cálcio: $16 \mathrm{mg}$; fósforo: $23 \mathrm{mg}$; ferro: $0,4 \mathrm{mg}$; sódio: $9,0 \mathrm{mg}$; vitamina $B_{1}: 0,05$ $\mathrm{mg}$; vitamina $\mathrm{B}_{2}: 0,03 \mathrm{mg}$; niacina: $0,3 \mathrm{mg}$ e vitamina $\mathrm{C}: 7,0 \mathrm{mg}$. Já a alface do tipo folha lisa apresentava a seguinte composição: água: $94,9 \%$; energia: $15 \mathrm{kcal}$; proteína: $1,3 \mathrm{~g}$; gordura: $0,2 \mathrm{~g}$; carboidratos totais: $2,9 \mathrm{~g}$; fibra: $0,7 \mathrm{~g}$; cálcio: $43 \mathrm{mg}$; fósforo: $34 \mathrm{mg}$; ferro: $1,3 \mathrm{mg}$; sódio: 9,0 $\mathrm{mg}$; vitamina $\mathrm{A}: 260 \mathrm{mg}$; vitamina $\mathrm{B}_{1}$ (tiamina): 0,08 $\mathrm{mg}$; vitamina $B_{2}$ (riboflavina): $0,08 \mathrm{mg}$; vitamina $B_{3}$ (niacina): $0,4 \mathrm{mg}$; vitamina $C: 12,0 \mathrm{mg}$. 
Segundo Martins \& Riella (1993), a alface possui por $100 \mathrm{~g}$ : energia: $16 \mathrm{kcal}$; proteína: 1,2 g; gordura: $0,2 \mathrm{~g}$; carboidratos totais: $2,3 \mathrm{~g}$; fibra: $0,7 \mathrm{~g}$; cálcio: $38 \mathrm{mg}$; fósforo: $42 \mathrm{mg}$; ferro: 1,1 mg; sódio: $12,0 \mathrm{mg}$; potássio: 140,0 mg; vitamina A (retinol) : 120ug; tiamina: $110,0 \mathrm{ug}$; riboflavina: $60,0 \mathrm{ug}$; niacina: $0,25 \mathrm{mg}$; vitamina C: $7,6 \mathrm{mg}$.

Segundo Filgueira (1982), a alface é classificada em quatro grupos:

a) Repolhuda manteiga : folhas lisas amanteigadas, formando uma típica cabeça repolhuda, bem compacta;

b) Repolhuda crespa: folhas crespas consistentes, formando uma cabeça compacta (cultivar americana);

c) Solta lisa: folhas lisas e soltas, mais ou menos delicadas, não forma cabeça compacta;

d) Solta crespa: folhas crespas consistentes, soltas, não formando cabeça.

e) Romana: folhas tipicamente alongadas, com nervuras claras e protuberantes, formando cabeça fofa e alongada.

É uma das hortaliças mais produzidas e consumidas em todo o mundo e, devido ao seu ciclo curto pode ser cultivada em quase todas as regiões, sendo necessária a existência de no mínimo dois meses de clima apto para o cultivo, quando cultivada a céu aberto. (Ohse, 1999)

No Brasil, as maiores zonas produtoras de alface encontram-se nos "cinturões verdes" (Vargem Grande, Mogi da Cruzes, Campinas, Jaboticabal, Piracicaba, entre outros, Belo Horizonte, Viçosa, Rio de Janeiro e no Rio Grande do Sul, Porto Alegre, Santa Maria e Vacaria), que circundam as grandes regiões metropolitanas do país. Isto ocorre devido a ser um produto apenas comercializável in natura, cujo transporte possui uma grande influência no custo final e, por ter seu preço de mercado muito afetado pela perda de água, a qual ocorre rapidamente pelas folhas (Bueno, 1998).

Por ser uma hortaliça de ciclo curto e crescimento rápido, ela é muito exigente quanto às condições climáticas, disponibilidade de água e nutrientes, para que ocorra um incremento acelerado de massa. O plantio da alface em estufas é o mais recomendado, pois consegue se um maior controle das condições climáticas, sendo que a cultura é exigente quanto às temperaturas mais amenas (Sganzerla, 1995). Em regiões de clima 
quente, não são utilizadas as cortinas laterais nas estruturas de proteção (Sganzerla, 1995).

\subsection{Propagação de plantas de alface para o cultivo hidropônico}

Furlani (1995) recomendou a propagação em bandejas de isopor, com células próprias para alface, utilizando um substrato, que pode ser vermiculita, perlite, areia lavada ou algodão. As sementes são enterradas $0,5 \mathrm{~cm}$ no substrato e as bandejas são colocadas sobre uma lâmina de água suficiente para manter o substrato úmido. Após a emergência das plântulas, deve-se trocar a água por solução diluída (25\%), permanecendo nessa condição até as plantas possuírem 4-5 folhas, para então serem transplantadas para as bancadas ou tubos.

Furlani et al. (1999) afirmaram que a escolha do substrato determinará o tipo de estrutura para produção de mudas. $\mathrm{O}$ substrato mais adequado deverá atender às seguintes características: ser inerte quanto ao fornecimento de nutrientes, ter $\mathrm{pH}$ neutro $\mathrm{e}$ apresentar retenção de água e porosidade adequadas para a oxigenação das raízes, oferecer sustentação para a muda e proteger as raízes de danos físicos. Para hortaliças folhosas (mudas) são quatro os mais usados: substrato organo-mineral, vermiculita, algodão hidrófilo e espuma fenólica. Para hortaliças de frutos, outros substratos podem ser usados, como perlita, lã-de-rocha, argila expandida e areia.

Faquim (1996) sugerem a utilização de bandejas contendo vermiculita ou mechas de algodão como substrato, as quais são mantidas em estufa com umidade adequada, até a germinação, sendo então transferidas para uma bancada onde as bandejas fiquem flutuando na mesma solução nutritiva utilizada para a fase de crescimento, não requerendo a adubação do substrato e não havendo a necessidade de adaptação das mudas em solução diluída a $50 \%$ ou menos. 


\subsection{Necessidades nutricionais de plantas de alface}

Em cultivos aeropônicos, a absorção é geralmente proporcional à concentração de nutrientes na solução próxima às raizes, sendo muito influenciada pelos fatores ambientais, tais como: salinidade, oxigenação, temperatura, $\mathrm{pH}$ da solução nutritiva, intensidade de luz, fotoperiodo, temperatura e umidade do ar (Adams, 1984).

Para a análise das plantas quanto às exigências nutricionais na solução nutritiva, deve-se enfocar as relações entre os nutrientes, sendo esta a relação de extração do meio de crescimento. No caso do cultivo hidropônico e aeropônico procura-se manter relativamente constantes as concentrações dos nutrientes no meio de crescimento, diferente do que ocorre no solo, pois nesse caso, a provisão das quantidades exigidas pelas plantas se dá pelo conhecimento prévio das quantidades disponíveis existentes no próprio solo.

A extração de nutrientes pela alface varia conforme a cultivar e a época do ano, ficando entre 8,0 a 16,0 mg de nitrogênio; 2,5 e 5,0 mg de fósforo e 11,5 e 13,0 mg de potássio por planta por dia e, durante o ciclo completo, têm-se: $0,45 \mathrm{~g}$ de nitrogênio; $0,15 \mathrm{~g}$ de fósforo e $0,7 \mathrm{~g}$ de potássio (Shippers, 1980). As quantidades de nutrientes extraídas durante o ciclo todo por plantas de alface do cultivar Verônica, são apresentadas no quadro 1 (Faquin et al.; 1996).

Quadro 1. Produção de material seco e extração de macro e micronutrientes, por 1000 plantas cultivadas em hidroponia de NFT (Faquin et al., 1996).

\begin{tabular}{|c|c|c|c|c|c|c|c|c|c|c|c|}
\hline Material seco & $\mathrm{N}$ & $\mathrm{P}$ & $\mathrm{K}$ & $\mathrm{Ca}$ & $\mathrm{Mg}$ & $\mathrm{S}$ & B & $\mathrm{Cu}$ & $\mathrm{Fe}$ & $\mathrm{Mn}$ & $\mathrm{Zn}$ \\
\hline & & & & & & & & \multicolumn{4}{|c|}{ g por 1.000 plantas------ } \\
\hline ----- & \multicolumn{7}{|c|}{ mg por 1.000 plantas ----- } & & & & \\
\hline 18.240 & 796 & 142 & 951 & 325 & 96 & 60 & 440 & 780 & 4.910 & 2.027 & 1.068 \\
\hline
\end{tabular}


Observa-se no quadro 1, que a extração total de nutrientes obedeceu a seguinte ordem decrescente: $\mathrm{K}>\mathrm{N}>\mathrm{Ca}>\mathrm{P}>\mathrm{Mg}>\mathrm{S}>\mathrm{Fe}>\mathrm{Mn}>\mathrm{Zn}>\mathrm{Cu}>\mathrm{B}$. Destaque-se a alta exigência das plantas de alface em $\mathrm{K}, \mathrm{N}, \mathrm{e} \mathrm{Ca}$, quando comparada com outras culturas (Faquin et al., 1996).

\subsection{Deficiência de Cálcio ou queima de bordos em alface}

$\mathrm{Na}$ cultura da alface, uma das desordens fisiológicas é causada, dentre outros fatores, pela deficiência de cálcio, sendo denominada "tipburn" ou queima de bordos. O sintoma se caracteriza por escurecimento (coloração marron) das folhas jovens que rapidamente se tornam necróticas, restringindo seu crescimento. Em condições de campo, o dano acontece quando a cabeça está formada, mais perto da maturidade, entretanto, em condições de estufas ou câmaras de crescimento, o tipburn pode desenvolver-se em plantas jovens, quando as folhas começam a dobrar, antes da formação da cabeça. Antes mesmo que o colapso marginal seja visto, havendo descoloração nas nervuras maiores das margens das folhas.

Este escurecimento é resultado da ruptura das células e do esparramamento do látex no tecido circunvizinho. A razão direta do colapso do tecido em células com baixas concentrações de cálcio não é ainda compreendida, mas vários fatores conduzem à conclusão de que a integridade da membrana é a fase inicial provável para desenvolvimento do dano, resultando, mais tarde, na debilidade da estrutura da parede celular (Collier, 1982).

Um dos primeiros trabalhos sobre a influência do cálcio no desenvolvimento do tipburn em alface foi publicado por Thibodeau e Minotti (1969). Aplicações foliares de $\mathrm{Ca}\left(\mathrm{NO}_{3}\right)_{2}$ ou $\mathrm{CaCl}_{2}$ controlaram completamente esse distúrbio na variedade de alface Meikoningen, quando direcionados para aa folhas imaturas susceptiveis. A análise de plantas tratadas ou não, mostrou que o conteúdo de cálcio em folhas susceptíveis 
aumentou e revelou um aumento de cinco vezes no seu conteúdo de cálcio.

Brumm \& Schenk (1993) estudaram a influência do suprimento de nitrogênio na incidência de "tipburn" em alface. O nitrato de cálcio foi aplicado nas taxas de 20 a 400 $\mathrm{kg} \mathrm{ha}^{-1}$ de $\mathrm{N}$, na cv.Captain e o tipburn aumentou com o suprimento de $\mathrm{N}$, em todos os experimentos. Este efeito direto do $\mathrm{N}$ sobre a injúria não foi acompanhado pela concentração baixa de cálcio nas folhas novas ou por mudanças na morfologia da cabeça, mas por uma diminuição na relação raiz / parte aérea. Na verdade, houve um aumento no tamanho da cabeça sem que o devido aumento proporcional da raiz ocorresse. Os autores concluiram que, em termos práticos, o risco de deficiência de cálcio pode ser diminuído, restringindo o suprimento de $\mathrm{N}$ a um nível ótimo.

Yanagi \& Bullock (1983) avaliaram a incidência de tipburn em alface "Crisphead" (americana) no Hawaii, monitorando mensalmente, de dezembro de 1979 a setembro de 1980, a temperatura ambiente máxima e mínima e o nível de nutrientes. O nível de nutrientes e a temperatura variaram de $0 \%$ em março a $90 \%$ em agosto (verão), o que demonstrou uma correlação alta entre a incidência de tipburn e a temperatura máxima elevada. Este fator tem sido considerado como o mais importante para promover a iniciação do desenvolvimento do tipburn, até porque, a temperatura dentro da cabeça, pode ser $6^{\circ} \mathrm{C}$ mais alta que a temperatura ambiente. A temperatura alta fez aumentar a taxa de crescimento da planta, de forma que absorção de nutrientes não acompanhasse a exigência do tecido e, assim, aparecesse o sintoma de deficiência. 


\subsection{Composição e manejo de soluções nutritivas}

A literatura está repleta de fórmulas de soluções, em termos de concentrações, sem referir-se como ela será utilizada, qual o volume por planta, qual a frequência de renovação e de reposição de nutrientes (Jones Jr., 1982).

Segundo Castellane \& Araújo (1994), quanto maior for o volume de solução por planta, menores serão as alterações nas concentrações dos nutrientes. Além disso, um volume maior por planta, permite um maior contato dos elementos essenciais com o sistema radicular e, uma diluição no efeito das substâncias tóxicas ou inibitórias (Jones Jr.,1983). Para alface, é recomendável utilizar-se volumes nunca inferiores a $1 \mathrm{~L}$ por planta (Carmello \& Furlani, 1994; Castellane \& Araújo, 1994 e Furlani, 1995 e Furlani et al,1999).

Segundo Jones Jr (1983), o monitoramento da solução pode ser relativamente fácil, mas nos ajustes, há uma maior dificuldade, devido ao volume da solução nutritiva e à frequência de utilização. A solução nutritiva precisa ser renovada de forma a compensar as quantidades de nutrientes retirados pelas culturas (Shippers, 1980).

Alguns cuidados são necessários para o uso e preparo de soluções nutritivas, tais como: (a) conhecer-se a qualidade da água, ou seja, suas características químicas (quantidade de nutrientes e concentração salina), (b) observar-se a relação custo / beneficio e solubilidade na escolha dos sais fertilizantes, (c) cuidar para que o nitrogênio na forma amoniacal não ultrapasse $20 \%$ da quantidade total de $\mathrm{N}$ na formulação, (d) evitar a mistura de solução concentrada de nitrato de cálcio com sulfatos e fosfatos, pois pode ocorrer a formação de compostos insolúveis (precipitados) como fosfato de cálcio e sulfato de cálcio, (e) preferir o uso de molibdato de amônio ou ácido molíbdico ao do molibdato de sódio, pois este é muito alcalino e, quando adicionado aos demais sais de micronutrientes pode ocasionar precipitações de alguns deles (Furlani et al ,1999). 


\subsection{Condutividade Elétrica (CE)}

A água é um péssimo condutor de eletricidade. Na presença de íons, ela apresenta a capacidade de conduzir eletricidade, propriedade essa denominada condutividade elétrica. Quanto maior a quantidade de íons na solução nutritiva, maior será a sua condutividade elétrica (CE) (Faquin et al., 1996).

A condutividade elétrica fornece informações sobre a concentração de sais na solução nutritiva, mas não permite conhecer-se as concentrações individuais dos macro e micronutrientes (Graves, 1983). Para ter-se uma idéia exata das concentrações, análises químicas são imprescindíveis (Castellane \& Araújo, 1984). A maneira mais correta de se avaliar a necessidade de reposição de nutrientes é a análise química periódica da solução nutritiva, mas esta apresenta o inconveniente da demora na obtenção dos resultados e do seu custo (Faquin et al., 1996).

A condutividade elétrica ajuda na decisão por uma complementação da solução ou pela sua renovação total. A solução nutritiva utilizada em aeroponia tem alta concentração e, recomenda-se manter o valor da condutividade elétrica entre 2,2 e 2,7 $\mathrm{mS} \mathrm{cm}^{-1}$ (Lee, 1998).

Furlani et al. (1999) recomendou que o volume do depósito deve ser completado com água, quantas vezes forem necessárias durante o dia, para evitar uma elevação muito grande na concentração salina da solução nutritiva.

A renovação da solução nutritiva também é recomendada para evitar-se o aumento nas concentrações de material orgânico (restos de plantas, exsudados de raízes e crescimento de algas) que pode servir como substrato para microorganismos.

Faquin et al. (1996) recomendaram que para a cultura de alface, a condutividade elétrica deve estar entre 2,0 e $2,5 \mathrm{mS} \mathrm{cm}^{-1}$, de modo que, quando o valor medido estiver abaixo dessa faixa, mais sais devem ser adicionados e, quando estiver acima, a solução seja diluída através da adição de água. 


\section{8 $\quad$ pH das soluções nutritivas}

$\mathrm{O}$ índice $\mathrm{pH}$ mede a atividade dos íons hidrogênio $\left(\mathrm{H}^{+}\right)$na solução. Conforme Castellane (1994), as plantas toleram uma amplitude maior de $\mathrm{pH}$ em soluções nutritivas do que no solo. Jones Jr. (1983) afirmou que o pH da solução é menos crítico nas soluções recirculantes do que nas estáticas, desde que esteja na faixa de 5,0 até 7,0. Embora, para aeroponia, se considere como ideal, que ela esteja na faixa de 5,0 a 6,0 (Lee \& Jie, 1998)

Carmello \& Furlani, (1994) recomendaram a manutenção do pH entre 5,0 e 7,0, mas indicaram como sendo mais adequada a faixa de 6,0 a 6,5 , o que concorda com Jones Jr. (1983). Faquin et al., (1996) indicou, para a cultura da alface, que o pH da solução fosse mantido entre 5,5 e 6,5.

$\mathrm{O}$ controle do $\mathrm{pH}$ das soluções nutritivas é de suma importância em cultivos aeropônicos e hidropônicos. $\mathrm{O}$ pH da solução está estreitamente relacionada com as fontes de nitrogênio, em particular, e com a composição da solução, em geral. A maioria das soluções possui valores de pH entre 5,0 e 6,0; sendo que, as de $\mathrm{pH}$ abaixo de 4,0 inibem a absorção de $\mathrm{K}^{+}$e $\mathrm{Ca}^{2+}$. Por outro lado, valores de $\mathrm{pH}$ acima de 6,5 causam deficiência de ferro e outros micronutrientes, devido à sua precipitação. Valores extremos de $\mathrm{pH}$ (menores que 4,0 e maiores que 9,0) podem causar toxicidade às raízes, diminuindo seu crescimento. Plantas cultivadas em solução nutritiva toleram maiores variações no seu pH do que no solo (Castellane \& Araújo, 1995).

Grande parte das soluções nutritivas têm capacidade tampão, dessa forma o pH varia continuamente, não se mantendo dentro de uma faixa ideal. As variações na faixa de 4,5 a 7,5 são toleradas sem problemas, promovendo o crescimento das plantas. No entanto, valores abaixo de $\mathrm{pH} 4,0$ afetam a integridade das membranas celulares e quando estão acima de 6,5, deve-se atentar para possíveis sintomas de deficiência de Fe, P, B e $\mathrm{Mn}$. 
As variações de $\mathrm{pH}$ que ocorrem na solução nutritiva são reflexo da absorção diferenciada de cátions e ânions. Quando o $\mathrm{N}$ é fornecido na forma nítrica, a absorção de ânions é maior que a de cátions ocorrendo elevação do $\mathrm{pH}$, por isso é importante o fornecimento de uma parte do $\mathrm{N}$ na forma amoniacal, tornando a solução mais tamponada. $\mathrm{O}$ importante é manter a solução nutritiva equilibrada em cátions e ânions para atender a demanda da planta (Furlani et al., 1999).

$\mathrm{O} \mathrm{pH}$ afeta a disponibilidade dos nutrientes, principalmente os micronutrientes, estimulando uma absorção excessiva em pH baixo, e a sua remoção da solução, por precipitação em pH elevado (Jones Jr, 1983). Nos valores baixos, ocorre competição entre os íons $\mathrm{H}^{+}$e os cátions nutrientes $\left(\mathrm{NH}_{4}^{+}, \mathrm{K}^{+}, \mathrm{Ca}^{+2}, \mathrm{Mg}^{+2}, \mathrm{Cu}^{+2}, \mathrm{Fe}^{+2}, \mathrm{Mn}^{+2}, \mathrm{Zn}^{+2}\right)$, além de, em valores de $\mathrm{pH}$ menores que 3,5 ocorrer um efeito tóxico direto dos íns $\mathrm{H}^{+}$ sobre as células vegetais (Carmello \& Furlani, 1994). Em pH alcalino, além da diminuição da absorção dos nutrientes aniônicos da solução $\left(\mathrm{NO}_{3}^{-}, \mathrm{SO}_{4}^{-2}, \mathrm{Cl}, \mathrm{MoO}_{4}{ }^{-2}\right)$ por competição com os ânions $\mathrm{OH}$, ocorre também a precipitação de $\mathrm{Fe}^{+2}, \mathrm{Mn}^{+2}$ e $\mathrm{Zn}^{+2}$ (Faquin et al.,1996).

$\mathrm{O}$ controle do $\mathrm{pH}$ é importante para se manter os nutrientes em solução e, evitarse a deficiência ou toxicidade por absorção excessiva, sendo que o $\mathrm{pH}$ pode ser controlado pela adição de bases $(\mathrm{NaOH} 1 \mathrm{~N})$, quando estiver abaixo de 5,5 ou de ácidos $(\mathrm{HCl} 1 \mathrm{~N})$ quando estiver acima de 6,5 


\section{MATERIAL E MÉTODOS}

\subsection{Condições experimentais}

$\mathrm{O}$ experimento foi conduzido em casa-de-vegetação, em estrutura própria para o sistema de cultivo de alface (Lactuca sativa, L.) em aeroponia, no setor de Nutrição Mineral de Plantas do Departamento de Solos e Nutrição de Plantas, da Escola Superior

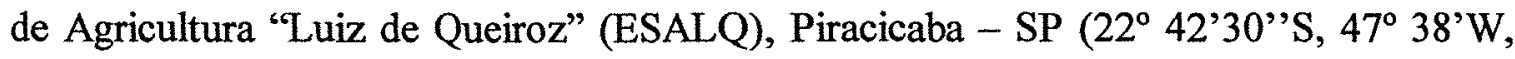
$546 \mathrm{~m})$ no período de $1^{\circ}$ de julho de 2000 a 15 de agosto de 2000 . Os valores das temperaturas máximas e mínimas e das umidades relativas do ar máximas e mínimas, tomados no interior da casa-de-vegetação, constam no anexo A. Neste anexo, também constam os valores de $\mathrm{pH}$ e da condutividade elétrica (CE) das soluções-tratamentos.

Para a montagem do sistema aeropônico foram usados tubos de PVC de $333 \mathrm{~mm}$ de diâmetro (policloreto de vinila) com $3 \mathrm{~m}$ de altura. Foram colocadas em média 46 plantas por tubo ou cohna. As caixas coletoras $(50 \mathrm{~cm}$ de comprimento X $42 \mathrm{~cm}$ de largura) estavam dispostas com $57 \mathrm{~cm} \mathrm{X} 55 \mathrm{~cm}$, uma das outras. As bombas da marca Jacuzzi modelo: C56J - 7,2/3,6A de $1 / 2 \mathrm{CV}-3430 \mathrm{rpm}$ FS $1,50-60 \mathrm{~Hz}$, circulavam a solução nutritiva, sendo 3 bombas uma para cada solução num tanque de 200L. Os bicos da marca Insigne para a aeroponia tem pressão de $1 \mathrm{~kg}$ e vazão de $80-100 \mathrm{~L} / \mathrm{h}$. 

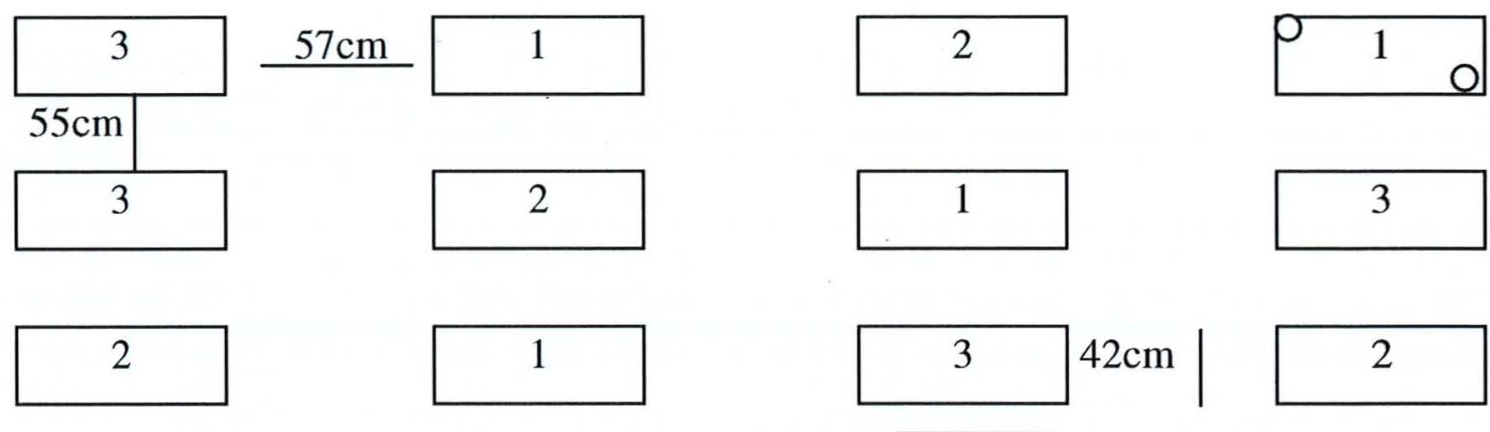

$50 \mathrm{~cm}$

1: Solução com $8,55 \mathrm{mmol}$. $\mathrm{L}^{-1}$ de cálcio (alta dose de cálcio)

2: Solução com 5,70 mmol. $\mathrm{L}^{-1}$ de cálcio (completa)

3: Solução com 2,85 mmol. $\mathrm{L}^{-1}$ de cálcio (baixa dose de cálcio)

Figura 1. Croqui de disposição das caixas coletoras com os respectivos tratamentos.

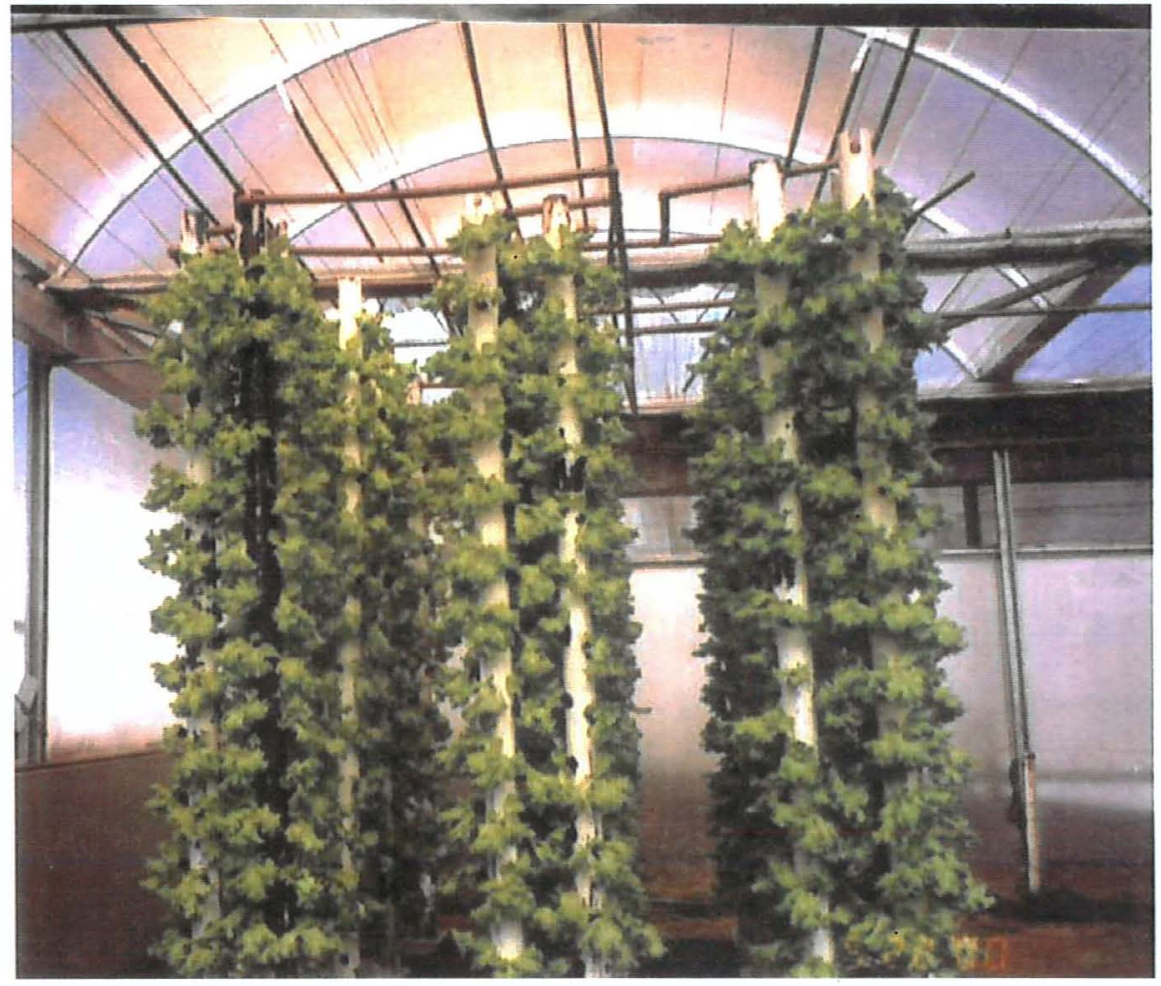

Figura 2. Vista geral do experimento. 


\subsection{Delineamento Experimental}

Foi utilizado o delineamento experimental parcelas subsubdivididas com quatro repetições. Os resultados da massa de material fresco e seco da parte aérea e das raízes, e composição de nutrientes minerais foram submetidos à análise de variância com o programa estatístico SANEST, usando-se o teste de Tukey a 5\% para a comparação de médias.

\subsection{Soluções nutritivas e condução do experimento}

Para o preparo das soluções nutritivas foram usados os seguintes sais/fertilizantes: cloreto de cálcio $(22 \% \mathrm{Ca}$ e $38 \% \mathrm{Cl})$, nitrato de cálcio Hydro $\left(19 \% \mathrm{Ca}, 14,5 \% \mathrm{~N}-\mathrm{NO}_{3}\right.$ e $\left.1 \% \mathrm{~N}^{-\mathrm{NH}_{4}}\right)$, sulfato de magnésio $\left(10 \% \mathrm{Mg}\right.$ e $\left.13 \% \mathrm{~S}_{-} \mathrm{SO}_{4}\right)$, nitrato de potássio $(36 \% \mathrm{Ke}$ $13 \% \mathrm{~N}^{-\mathrm{NO}_{3}}$ ), cloreto de potássio $(52 \% \mathrm{~K} \mathrm{e} 47 \% \mathrm{Cl})$; fosfato monoamônio (11\% $\mathrm{N}-\mathrm{NH}_{4}$ , 21\% P), nitrato de amônio (16,5\% $\mathrm{N}-\mathrm{NO}_{3}$ e $\left.16,5 \% \mathrm{~N}-\mathrm{NH}_{4}\right)$, nitrato de sódio $(27 \% \mathrm{Na}$ e $16,5 \% \mathrm{~N}-\mathrm{NO}_{3}$ ), ácido bórico (17\% B), sulfato de manganês ( $26 \% \mathrm{Mn}$ e $21 \% \mathrm{~S}_{-} \mathrm{SO}_{4}$ ), sulfato de zinco $\left(22 \% \mathrm{Zn}\right.$ e $\left.11 \% \mathrm{~S}_{-} \mathrm{SO}_{4}\right)$, sulfato de cobre $\left(13 \% \mathrm{Cu}\right.$ e $\left.12 \% \mathrm{~S}-\mathrm{SO}_{4}\right)$, molibdato de sódio ( $39 \% \mathrm{Mo} \mathrm{e} \% \mathrm{Na})$; sulfato ferroso $\left(20 \% \mathrm{Fe}\right.$ e $\left.11 \% \mathrm{~S}_{-} \mathrm{SO}_{4}\right)$, etileno diamino tetraacetato dissódico.

Foram preparadas três soluções nutritivas com concentrações variadas de cálcio conforme indicadas no quadro 2 e acrescidas de $1 \mathrm{~mL} \cdot \mathrm{L}^{-1}$ de soluções de micronutrientes e de ferro. Para o preparo de $1 \mathrm{~L}$ de solução de micronutrientes foram dissolvidas as seguintes quantidades de cada sal: ácido bórico $2,86 \mathrm{~g}$; sulfato de manganês $1,81 \mathrm{~g}$; sulfato de zinco $0,10 \mathrm{~g}$; sulfato de cobre $0,04 \mathrm{~g}$ e ácido molíbdico $0,02 \mathrm{~g}$. A solução de ferro foi preparada com os seguintes sais: EDTA dissódico: $26,1 \mathrm{~g}$; sulfato de ferroso: 24 g e hidróxido de sódio: $11,44 \mathrm{~g}$. 
A solução nutritiva foi preparada, utilizando-se a água existente no local do experimento, cujo valor de $\mathrm{pH}$ foi de 7,3 e condutividade elétrica $0,17 \mathrm{mS} \mathrm{cm}^{-1}$. As concentrações (mmol L ${ }^{-1}$ ) dos nutrientes na água eram de: 0,05 de $\mathrm{K} ; 0,53 \mathrm{de} \mathrm{Ca}, 0,17 \mathrm{de}$ $\mathrm{Mg} ; 0,75$ de S; 0,02 de Fe e 0,27 de Na. Para o preparo das soluções nutritivas, esses valores não foram levados em consideração. $O$ volume de solução utilizado foi de 1,83 litros por planta. Durante o período diurno, a solução foi circulada em intervalos de 6 minutos por períodos de 6 minutos e, durante o período noturno a intervalos de 2 horas por períodos de 10 minutos. Esse controle do período noturno e diurno foi feito por um temporizador ("timer"), equipado com sensor fotoelétrico.

O cultivar Vera, que foi utilizado, é do tipo alface repolhuda crespa, recomendada para as condições de verão, podendo ainda ser cultivada o ano inteiro e, tendo alta resistência ao pendoamento. (Schmidt, 1998)

A semeadura foi feita em bandejas de isopor com 288 células para alface, preenchidas com vermiculita. A solução nutritiva sob as bandejas foi recirculada de três a quatro vezes por dia, manualmente, para promover a sua oxigenação. 


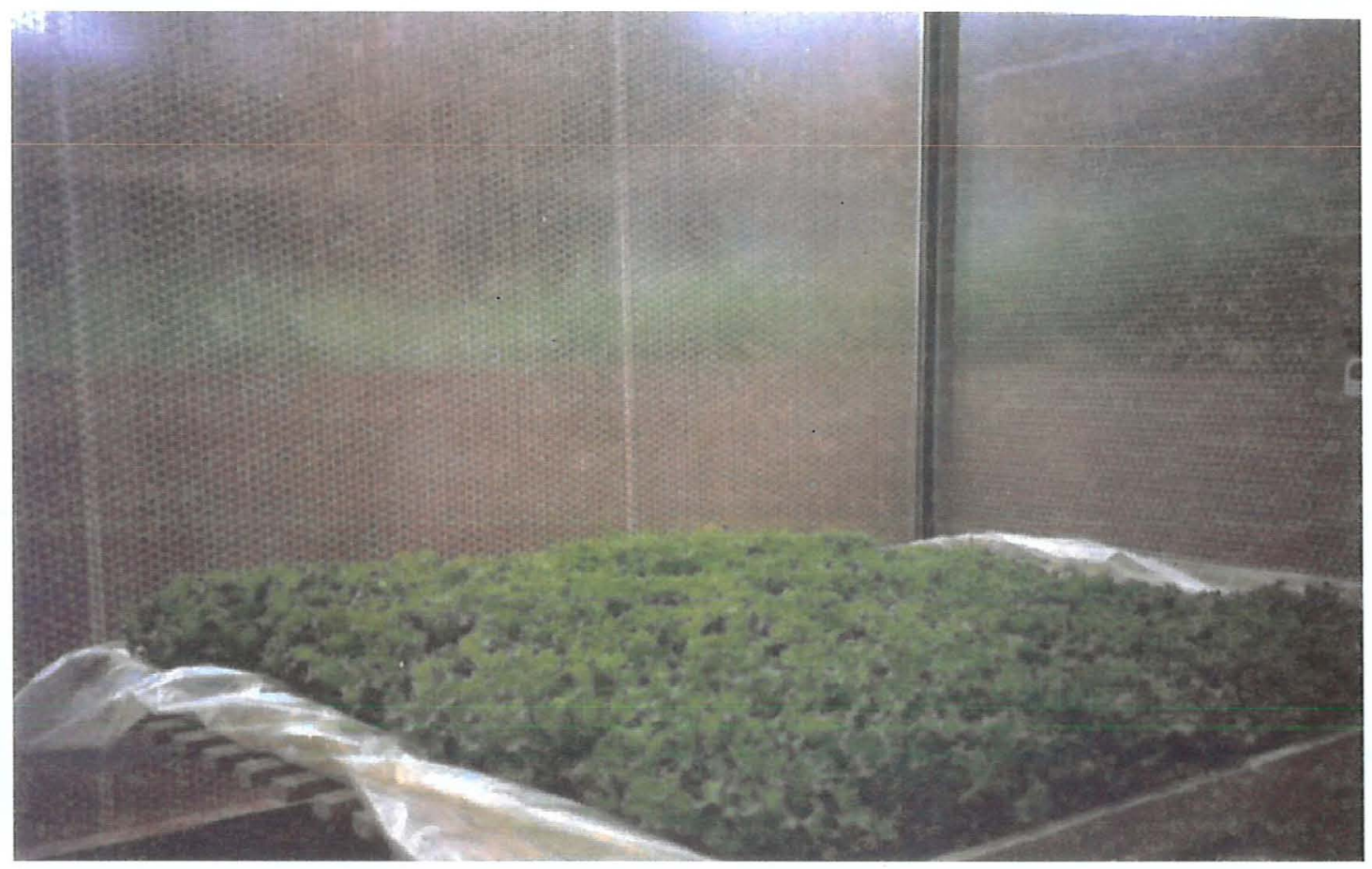

Figura 2. Vista das mudas por ocasião do transplante.

Foram feitas coletas diárias de amostras de solução de cada tratamento, para o monitoramento da condutividade elétrica e do $\mathrm{pH}$. 


\subsection{Amostragens e determinações}

Foram coletadas três plantas por tubo ou coluna, no total de 72 plantas ( 3 plantas X 24 tubos), sendo uma planta da parte superior, uma da intermediária e a última da parte inferior, no final do ciclo (45 dias após o transplante). As plantas foram separadas em parte aérea e sistema radicular. As raizes foram lavadas com $\mathrm{HCl} 0,1 \mathrm{~N}$ e enxaguadas com água destilada para retirar os nutrientes que porventura estivessem aderidos a elas. Após a lavagem, as raizes foram envolvidas com papel absorvente para retirar o excesso de água. Foram feitas pesagens da massa de material fresco da parte aérea e das raizes de cada planta. Após essas pesagens, as amostras foram acondicionadas em sacos de papel para a secagem em estufa com circulação forçada de ar a $65^{\circ} \mathrm{C}$, até atingirem massa constante. Efetuou-se nova pesagem, para avaliar-se a massa do material seco e, após, as amostras foram moídas uma a uma, utilizando o moinho tipo Wiley e acondicionadas em sacos de polietileno, para serem submetidas à análise química.dos teores de macro e micronutrientes conforme metodologia descrita por Sarruge \& Haag (1974). 
Quadro 2. Relação dos sais ou fertilizantes, concentrações de cada um e respectivas concentrações dos elementos componentes das soluções tratamentos.

Sal ou Fertilizante

g/L Cátion $\quad \mathrm{S}_{-} \mathrm{SO}_{4}, \mathrm{~N}-\mathrm{NO}_{3}, \mathrm{Cl}$ ou H $\mathrm{H}_{2} \mathrm{PO}_{4} \quad \mathrm{~N}-\mathrm{NH}_{4}$

Solução 1

$\mathrm{mmol} \mathrm{L}^{-1}$

Nitrato de cálcio

$1,2 \quad 5,70$

12,43

0,86

Sulfato de magnésio

0,5

2,08

2,03

Nitrato de potássio

0,26

2,40

2,41

Cloreto de potássio

0,25

3,33

3,31

Fosfato monoamônio

0,15

1,02

1,18

Cloreto de cálcio

0,518

2,85

5,54

Solução 2

Nitrato de cálcio

1,2

5,70

$\mathrm{mmol} \mathrm{L}^{-1}$

Sulfato de magnésio

0,5

2,08

12,43

0,86

Nitrato de potássio

0,26

2,40

2,03

2,41

Cloreto de potássio

0,25

3,33

3,31

Fosfato monoamônio

0,15

1,02

1,18

Solução 3

Nitrato de cálcio

0,6

2,85

$\operatorname{mmol~L} \mathrm{L}^{-1}$

Sulfato de magnésio

0,5

2,08

6,22

0,86

Nitrato de potássio

0,26

2,40

2,03

2,41

Cloreto de potássio

0,25

3,33

3,31

Fosfato monoamônio

0,15

1,02

1,18

Nitrato de amônio

0,0364

0,43

0,43

Nitrato de sódio

0,494

5,80

5,82 


\section{RESULTADOS E DISCUSSÃO}

\subsection{Acúmulo de material fresco e seco da parte aérea e das raízes, porcentagem do material seco da parte aérea e raízes e as relações parte aérea / raízes}

Os resultados referentes ao acúmulo de material fresco e seco da parte aérea e das raízes e as relações entre o material seco da parte aérea e das raízes de plantas em função das três soluções e as posições nos tubos ou colunas, encontram-se nas tabelas 1 a 4 .

A análise de variância revelou diferenças significativas $(P<0,05)$ para a produção de material fresco da parte aérea (MFPA) entre as soluções e posições das plantas nos tubos ou colunas no sistema de aeroponia (Tabela 1). A solução com a menor dose de cálcio proporcionou a maior média de produção de alface $\left(82,36 \mathrm{~g} \mathrm{~kg}^{-1}\right)$, diferindo da solução com a maior dose de cálcio.

Quanto ao posicionamento das plantas nos tubos, as plantas que estavam na posição superior na dose menor de cálcio diferiu significativamente das plantas que estavam na posição intermediária e inferior. Sendo que as plantas da posição superior mostraram maior produção de massa fresca estatisticamente diferentes daquelas das posições intermediária e inferior.

Neste tratamento havia $2,85 \mathrm{mmol} \mathrm{L}^{-1}$ de cálcio $\left(114 \mathrm{mg} \mathrm{L}^{-1}\right),\left(299,6 \mathrm{mg} \mathrm{L}^{-1}\right.$ de $\left.\mathrm{N}\right)$ e (223,5 mg L $\left.\mathrm{L}^{-1} \mathrm{de} \mathrm{K}\right)$.

Ruschel (1998), em estudo realizado no mesmo local, com a cultivar Vera, conseguiu a produção máxima de massa fresca de $164,66 \mathrm{~g}$, com a dose conjunta de 5,70 mmol $\mathrm{L}^{-1}$ de cálcio, $18,55 \mathrm{mmol} \mathrm{L}^{-1}$ de $\mathrm{N}$ e $7,16 \mathrm{mmol} \mathrm{L}^{-1}$ de $\mathrm{K}$ na solução nutritiva, no sistema NFT (Nutrient Film Technique) em hidroponia.

Enquanto Koefender (1996), verificou uma produção de material fresco da parte aérea de $183,93 \mathrm{~g}$ por planta, para a cultivar Verônica, utilizando conjuntamente 5,70 
mmol $\mathrm{L}^{-1}$ de cálcio, $14,05 \mathrm{mmol} \mathrm{L}^{-1}$ de $\mathrm{N}$ e $5,93 \mathrm{mmol} \mathrm{L}^{-1}$ de $\mathrm{K}$ na solução nutritiva no sistema NFT (Nutrient Film Technique) em hidroponia.

Zito et al. (1994), utilizando a cultivar Vitória verde-clara, obtiveram 122,5 g por planta no tratamento mais produtivo.

Comparando-se a massa de material fresco das raízes entre os tratamentos, não se observou diferenças significativas entre as médias para as soluções nutritivas, sendo que o mesmo ocorreu quanto ao posicionamento das plantas nos tubos verticais, com exceção do tratamento com menor dose de cálcio, que resultou na maior produção de massa de raízes na posição superior.(Tabela 1)

As plantas localizadas na posição superior e que receberam solução com menor concentração de cálcio apresentaram maiores pesos do material fresco da parte aérea.

A análise de variância para a produção de material seco da parte aérea (MSPA) revelou diferenças significativas $(\mathrm{P}<0,05)$ para o posicionamento das plantas nos tubos ou colunas (Tabela 2).

As médias de material seco da parte aérea, em função da posição nos tubos, diferiram estatisticamente entre si. As maiores médias foram obtidas para a posição superior dos tubos.

As médias de material seco das raízes, não diferiram estatisticamente entre as soluções nutritivas, mas diferiram estatisticamente, para o posicionamento das plantas de alface nas colunas do sistema de aeroponia (Tabela 2).

A produção de material seco das raizes foi afetada somente na posição inferior dos tubos, sendo estatisticamente diferente das médias de produção na posição superior. Na posição intermediária, a solução nutritiva completa diferiu estatisticamente da solução com menor dose de cálcio.

Ruschel (1998) atingiu uma produção máxima da MSPA de 6,7 g por planta nas doses conjuntas 5,70 mmol $\mathrm{L}^{-1}$ de cálcio, 14,05 $\mathrm{mmol} \mathrm{L}^{-1}$ de $\mathrm{N}$ e 5,93 mmol $\mathrm{L}^{-1}$ de $\mathrm{K}$ na solução nutritiva no sistema NFT (Nutrient Film Technique) em hidroponia, para a cultivar Vera. 
Furlani (1995), utilizando conjuntamente $13,93 \mathrm{mg} \mathrm{L}^{-1}$ de $\mathrm{N}$ e 4,69 $\mathrm{mg} \mathrm{L}^{-1}$ de $\mathrm{K}$ na solução nutritiva, obteve uma produção de MS de parte aérea por planta de $10,5 \mathrm{~g}$ e $15,7 \mathrm{~g}$, para as cultivares Marisa e Verônica, respectivamente no sistema NFT em hidroponia.

Os resultados obtidos por Ruschel (1998) revelaram que a produção máxima de massa de material seco para a cultivar Vera foi de $14,27 \mathrm{~g}$ na dose conjunta estimada de $5,70 \mathrm{mmol} \mathrm{L}^{-1}$ de cálcio, 14,05 mmol $\mathrm{L}^{-1}$ de $\mathrm{N}$ e $5,93 \mathrm{mmol} \mathrm{L}^{-1}$ de $\mathrm{K}$ na solução nutritiva no sistema NFT (Nutrient Film Technique) em hidroponia.

Costa et al. (1997) encontraram resultados de MS da planta inteira, em hidroponia, para a cultivar Vera $(6,73 \mathrm{~g})$. As diferenças dos resultados desses autores em relação aos deste experimento poderiam ser devidos às cultivares diferentes, à duração do experimento, aos diferentes sistemas de produção (hidroponia / aeroponia), ao volume de solução nutritiva por planta e à época do ano.

Quanto à porcentagem de material seco da parte aérea, os tratamentos estudados em relação à concentração de cálcio não diferiram estatisticamente e, quanto ao posicionamento, as plantas da posição superior diferiram significativamente daquelas da posição inferior (Tabela 3).

As raizes da posição superior diferiram significativamente das médias das posições intermediária e inferior. A solução nutritiva completa resultou nas maiores médias de porcentagem de massa de material seco de raízes, que diferiram estatisticamente das médias das soluções com a maior dose de cálcio.

Não houve diferença significativa entre os tratamentos para a relação parte aérea / raiz pelo teste de Tukey, indicando que as doses de cálcio ou a posição das plantas não afetaram a proporção de massa de cada uma das partes. (Tabela 4) 
Tabela 1. Acúmulo de material fresco da parte aérea e das raízes de plantas de alface cv. Vera cultivadas em soluções nutritivas, em função das concentrações de cálcio e da posição no tubo vertical.

\begin{tabular}{|c|c|c|c|c|}
\hline \multicolumn{5}{|c|}{ Concentração de cálcio, $\mathrm{mmol} \mathrm{L}^{-1}$} \\
\hline & 8,55 & 5,70 & 2,85 & \\
\hline Posição & \multicolumn{3}{|c|}{ g por planta $\left({ }^{*}\right)$} & Médias $^{(1)}$ \\
\hline \multicolumn{5}{|c|}{ Material fresco da parte aérea } \\
\hline Superior & $65,32 \mathrm{~B} \mathrm{a}$ & $75,44 \mathrm{~B} \mathrm{a}$ & $104,47 \mathrm{~A} \mathrm{a}$ & $81,74 \mathrm{~A}$ \\
\hline Mediana & $70,09 \mathrm{~A} \mathrm{a}$ & $77,11 \mathrm{~A} \mathrm{a}$ & $66,51 \mathrm{Ab}$ & $71,23 \mathrm{~A}$ \\
\hline Inferior & $66,46 \mathrm{~A} \mathrm{a}$ & $71,13 \mathrm{~A} \mathrm{a}$ & $76,09 \mathrm{~A} \mathrm{~b}$ & $71,23 \mathrm{~A}$ \\
\hline Médias $^{(2)}$ & $67,29 \mathrm{~A}$ & $74,56 \mathrm{~A}$ & $82,36 \mathrm{~A}$ & 74,73 \\
\hline \multicolumn{5}{|c|}{ Material fresco das raízes } \\
\hline Superior & $12,38 \mathrm{~A} \mathrm{a}$ & $12,81 \mathrm{~A} \mathrm{a}$ & $16,18 \mathrm{~A} \mathrm{a}$ & $13,79 \mathrm{~A}$ \\
\hline Mediana & $14,43 \mathrm{~A}$ a & $14,02 \mathrm{~A} \mathrm{a}$ & $7,01 \mathrm{~A} \mathrm{~b}$ & $11,82 \mathrm{~A}$ \\
\hline Inferior & $10,27 \mathrm{~A} \mathrm{a}$ & $7,36 \mathrm{~A} \mathrm{a}$ & $14,31 \mathrm{~A} \mathrm{ab}$ & $10,64 \mathrm{~A}$ \\
\hline Médias $^{(2)}$ & $12,36 \mathrm{~A}$ & $11,39 \mathrm{~A}$ & $12,50 \mathrm{~A}$ & 12,08 \\
\hline
\end{tabular}

$\left({ }^{*}\right)$ Valores seguidos por letras iguais não diferem estatísticamente a $5 \%$ pelo teste de Tukey para a comparação entre o fator posição ${ }^{(1)}$ e o fator concentração de cálcio ${ }^{(2)}$. Para a interação concentração de cálcio e posição, as letras minúsculas comparam médias entre posições dentro de uma mesma concentração de cálcio e as letras maiúsculas comparam médias entre concentrações de cálcio dentro de uma mesma posição no tubo vertical. 
Tabela 2. Acúmulo de material seco da parte aérea e das raízes de plantas de alface cv. Vera cultivadas em soluções nutritivas em função das concentrações de cálcio e da posição no tubo vertical.

\begin{tabular}{|c|c|c|c|c|}
\hline \multicolumn{5}{|c|}{ Concentração de cálcio, $\mathrm{mmol} \mathrm{L}^{-1}$} \\
\hline & 8,55 & 5,70 & 2,85 & \multirow[b]{2}{*}{ Médias $^{(1)}$} \\
\hline Posição & \multicolumn{3}{|c|}{$\begin{array}{c}\text { g por planta }\left({ }^{*}\right) \\
\text { Material seco da parte aérea }\end{array}$} & \\
\hline Superior & 2,25 & 2,98 & 3,87 & $3,03 \mathrm{~A}$ \\
\hline Mediana & 1,97 & 2,96 & 1,83 & $2,26 \mathrm{~B}$ \\
\hline Inferior & 1,78 & 2,30 & 2,26 & $2,11 \mathrm{~B}$ \\
\hline Médias $^{(2)}$ & $2,00 \mathrm{~A}$ & $2,75 \mathrm{~A}$ & $2,65 \mathrm{~A}$ & 2,47 \\
\hline \multicolumn{5}{|c|}{ Material seco das raizes } \\
\hline Superior & $0,64 \mathrm{~A} \mathrm{a}$ & $1,04 \mathrm{~A} \mathrm{a}$ & $1,07 \mathrm{~A} \mathrm{a}$ & $0,91 \mathrm{~A}$ \\
\hline Mediana & $0,72 \mathrm{AB}$ a & $0,90 \mathrm{~A} \mathrm{ab}$ & $0,38 \mathrm{~B} \mathrm{~b}$ & $0,67 \mathrm{AB}$ \\
\hline Inferior & $0,47 \mathrm{~A} \mathrm{a}$ & $0,51 \mathrm{~A} \mathrm{~b}$ & $0,80 \mathrm{~A} \mathrm{ab}$ & $0,59 \mathrm{~B}$ \\
\hline Médias ${ }^{(2}$ & $0,61 \mathrm{~A}$ & $0,82 \mathrm{~A}$ & $0,75 \mathrm{~A}$ & 0,72 \\
\hline
\end{tabular}

$\left(^{*}\right)$ Valores seguidos por letras iguais não diferem estatisticamente a $5 \%$ pelo teste de Tukey para a comparação entre o fator posição ${ }^{(1)}$ e o fator concentração de cálcio(2). Para a interação entre a concentração de cálcio e a posição, as letras minúsculas comparam médias entre posições dentro de uma mesma concentração de cálcio e as letras maiúsculas comparam médias entre concentrações de cálcio dentro de uma mesma posição no tubo vertical. 
Tabela 3. Porcentagem de material seco da parte aérea e das raízes de plantas de alface cv. Vera cultivadas em soluções nutritivas em função das concentrações de cálcio e da posição no tubo vertical.

\begin{tabular}{|c|c|c|c|c|}
\hline \multicolumn{5}{|c|}{ Concentração de cálcio, $\mathrm{mmol} \mathrm{L}^{-1}$} \\
\hline & 8,55 & 5,70 & 2,85 & \multirow[b]{2}{*}{ Médias $^{(1)}$} \\
\hline Posição & \multicolumn{3}{|c|}{$\begin{array}{l}\text { g por planta }\left({ }^{*}\right) \\
\text { Material seco da parte aérea }(\%)\end{array}$} & \\
\hline Superior & 3,47 & 3,96 & 3,67 & $3,70 \mathrm{~A}$ \\
\hline Mediana & 2,84 & 3,75 & 2,74 & $3,11 \mathrm{AB}$ \\
\hline Inferior & 2,62 & 3,09 & 2,85 & $2,85 \mathrm{~B}$ \\
\hline Médias $^{(2)}$ & $2,98 \mathrm{~A}$ & $3,60 \mathrm{~A}$ & $3,09 \mathrm{~A}$ & 3,22 \\
\hline \multicolumn{5}{|c|}{ Material seco das raizes (\%) } \\
\hline Superior & 5,16 & 9,38 & 6,67 & $7,07 \mathrm{~A}$ \\
\hline Mediana & 5,08 & 6,45 & 5,58 & $5,70 \mathrm{~B}$ \\
\hline Inferior & 4,58 & 6,88 & 5,60 & $5,69 \mathrm{~B}$ \\
\hline Médias $^{(2)}$ & 4,94 B & $7,57 \mathrm{~A}$ & $5,95 \mathrm{AB}$ & 6,15 \\
\hline
\end{tabular}

$\left({ }^{*}\right)$ Valores seguidos por letras iguais não diferem estatísticamente a $5 \%$ pelo teste de Tukey para a comparação entre o fator posição ${ }^{(1)}$ e o fator concentração de cálcio ${ }^{(2)}$. Para a interação concentração de cálcio e posição, letras minúsculas comparam as médias entre as posições dentro de uma mesma concentração de cálcio e letras maiúsculas comparam as médias entre concentrações de cálcio dentro de uma mesma posição no tubo vertical. 
Tabela 4. Relação da parte aérea / raízes de plantas de alface cv. Vera cultivadas em soluções nutritivas em função das concentrações de cálcio e da posição no tubo vertical.

\begin{tabular}{|c|c|c|c|c|}
\hline \multicolumn{5}{|c|}{ Concentração de cálcio, $\mathrm{mmol} \mathrm{L}^{-1}$} \\
\hline & 8,55 & 5,70 & 2,85 & \multirow[b]{2}{*}{ Médias $^{(1)}$} \\
\hline Posição & \multicolumn{3}{|c|}{$\begin{array}{l}\text { g por planta }(*) \\
\text { Relação da parte aérea e das raízes (\%) }\end{array}$} & \\
\hline Superior & 3,94 & 3,20 & 5,05 & $4,06 \mathrm{~A}$ \\
\hline Mediana & 3,37 & 3,33 & 5,86 & $4,18 \mathrm{~A}$ \\
\hline Inferior & 3,82 & 5,08 & 3,07 & $3,99 \mathrm{~A}$ \\
\hline Médias $^{(2)}$ & $3,71 \mathrm{~A}$ & $3,87 \mathrm{~A}$ & $4,66 \mathrm{~A}$ & 4,08 \\
\hline
\end{tabular}

(*) Valores seguidos por letras iguais não diferem estatísticamente a $5 \%$ pelo teste de Tukey para a comparação entre o fator posiçãa ${ }^{(1)}$ e o fator concentração de cálcio ${ }^{(2)}$. Para a interação concentração de cálcio e posição, letras minúsculas comparam as médias entre as posições dentro de uma mesma concentração de cálcio e letras maiúsculas comparam as médias entre as concentrações de cálcio dentro de uma mesma posição no tubo vertical. 


\subsection{Acúmulo de macronutrientes na parte aérea e raízes}

\subsubsection{Nitrogênio}

Os resultados referentes ao acúmulo de nitrogênio, fósforo e potássio no material seco da parte aérea encontram-se nas tabelas 5 , a 7 .

Não foram observadas diferenças estatísticas entre as quantidades de nitrogênio na parte aérea das plantas da cultivar de alface Vera, quanto às soluções nutritivas e ao posicionamento das plantas nos tubos ou colunas (Tabela 5).

Houve um acúmulo maior de nitrogênio na parte aérea em relação ao sistema radicular, devido à grande mobilidade do nutriente para a parte aérea e a maior produção de massa da parte aérea em relação às raízes. Na média a solução completa resultou no maior acumulo de $\mathrm{N}(100,66 \mathrm{mg} /$ planta) mas não diferindo estatisticamente da solução nutritiva com maior dose de cálcio (menores valores $69,68 \mathrm{~g} \mathrm{~kg}^{-1}$ ).

Porém, a interação entre os tratamentos foi significativa e as plantas da posição superior e da solução com menor dose de cálcio, apresentaram o maior acúmulo de $\mathrm{N}$ na parte aérea.

Houve um decréscimo na quantidade de nitrogênio absorvida em função das doses de cálcio na solução nutritiva.

A concentração média de $\mathrm{N}$ na parte aérea das plantas da solução com menor dose de cálcio, na posição superior foi de $35 \mathrm{~g} \mathrm{~kg}^{-1}$.

Os resultados de concentração de nitrogênio na parte aérea foram inferiores aos observados por Faquin et al. (1996) e Costa et al. (1997), que encontraram $45 \mathrm{~g} \mathrm{~kg}^{-1} \mathrm{e}$ $60,4 \mathrm{~g} \mathrm{~kg}^{-1}$, para as cultivares Verônica e Babá, respectivamente. Por outro lado, estes resultados de concentração de nitrogênio na planta inteira foram similares aos encontrados por Koefender (1996), que obteve $36,4 \mathrm{~g} \mathrm{~kg}^{-1}$ para a cultivar Verônica. 
Para Ruschel (1998), a amplitude de valores foi de 174,3mg até $280,3 \mathrm{mg}$ de $\mathrm{N}$ na parte aérea para a cultivar Vera, diferente da amplitude obtida neste experimento, que foi de $66,40 \mathrm{mg}$ de $\mathrm{N}$ na parte aérea das plantas da solução nutritiva com maior dose de cálcio a $135,33 \mathrm{mg}$ na solução com menor dose de cálcio. Esses valores são menores do que aqueles encontrados por Costa et al. (1997), que obtiveram uma quantidade de nitrogênio absorvido de $366,0 \mathrm{mg}$ de $\mathrm{N}$ na parte aérea.

Não houve diferença significativa entre as médias, para as quantidades de nitrogênio nas raizes, para as soluções nutritivas mas houve no posicionamento das plantas nos tubos com interação significativa entre os tratamentos. O maior acúmulo de $\mathrm{N}$ nas raízes ocorreram para as plantas na posição superior da solução completa e, com menor dose de cálcio, correspondendo à posição onde se obteve a maior produção de massa de material fresco e seco de alface. (Tabela 5).

Ruschel (1998) obteve uma absorção máxima de nitrogênio pela planta inteira de $251,5 \mathrm{mg}$ de $\mathrm{N}$ na cultivar Vera, valores que são superiores aos encontrados neste experimento.

Furlani (1995), utilizando 13,93 mmol L $\mathrm{L}^{-1}$ de $\mathrm{N}$ na solução nutritiva, obteve uma quantidade de nitrogênio absorvido de $387 \mathrm{mg}$ e $588 \mathrm{mg}$ na planta inteira, para as cultivares Marisa e Verônica, respectivamente, em hidroponia NFT, sendo portanto, esses resultados superiores aos encontrados neste experimento. Resultados semelhantes aos constatados neste trabalho foram encontrados por Faquin et al. (1996), que obtiveram $257,5 \mathrm{mg}$ de $\mathrm{N}$ absorvido pela parte aérea, para a cultivar Verônica, 20 dias após o transplante no sistema de hidroponia NFT. 


\subsubsection{Fósforo}

A quantidade de fósforo no material seco da parte aérea não diferiu estatisticamente entre os tratamentos com as soluções nutritivas e as posições das plantas nos tubos ou colunas, que constam da Tabela 6.

Costa et al. (1997) encontraram valores de acúmulo na parte aérea mais elevados. Os resultados de acúmulo encontrados neste experimento, são semelhantes aos de Faquin et al. (1996) e Koefender (1996).

Ruschel (1998) obteve na planta inteira, a quantidade máxima de fósforo absorvido de 53,9 mg superiores para a cultivar de alface Vera no sistema de hidroponia.

Este mesmo autor obteve, para a cultivar Marisa, um acúmulo de $44,4 \mathrm{mg}$ de fósforo na planta inteira, também superiores aos encontrados neste experimento. As quantidades de $\mathrm{P}$ absorvidas foram menores que as encontradas por Costa et al. (1997) e Furlani (1995) no sistema de hidroponia em diferentes cultivares.

Para as quantidades de fósforo nas raízes houve interação significativa entre as soluções nutritivas e o posicionamento das plantas nos tubos (Tabela 6).

O maior acúmulo de fósforo ocorreu nas plantas da posição superior nas três soluções nutritivas.

\subsubsection{Potássio}

Na tabela 7 são apresentadas as quantidades de potássio acumuladas na parte aérea e nas raízes.

As quantidades de potássio na parte aérea, apresentaram diferenças significativas para a interação entre as soluções nutritivas e o posicionamento das plantas de alface nos tubos e as interações entre os tratamentos foram significativas (Tabela 7). 
Houve efeito significativo da solução nutritiva no acúmulo de potássio na parte aérea das plantas, sendo que os maiores acúmulos foram observados nas soluções com a menor dose de cálcio e diferiu em relação às posições, sendo que as plantas na posição superior acumularam mais potássio. Os resultados da concentração de potássio nos tecidos da parte aérea foram superiores $\left(80 \mathrm{~g} \mathrm{~kg}^{-1}\right)$ aos encontrados por Koefender (1996), que obteve $71,14 \mathrm{~g} \mathrm{~kg}^{-1}$ no tratamento mais produtivo, utilizando a cultivar Verônica, sendo o mesmo observado por Faquin et al. (1996), que encontraram concentrações inferiores $\left(54 \mathrm{~g} \mathrm{~kg}^{-1}\right)$ aos deste experimento.

Costa et al. (1997) encontraram concentrações similares $\left(82,9 \mathrm{~g} \mathrm{~kg}^{-1}\right)$ na parte aérea, para a cultivar de alface Babá. As concentrações encontradas na parte aérea e na planta inteira estão dentro da faixa de concentração considerada adequada para a cultura (Reuter \& Robinson,1997).

Ruschel (1998) obteve a concentração máxima de potássio na parte aérea, para a cultivar Vera, em $78,42 \mathrm{~g} \mathrm{~kg}^{-1}$, nas doses similares à solução nutritiva completa deste experimento. A concentração máxima de potássio na planta inteira da cultivar Vera foi de $76,9 \mathrm{~g} \mathrm{~kg}^{-1}$, inferiores ao presente experimento que obteve valores de $92 \mathrm{~g} \mathrm{~kg}^{-1}$ na planta inteira. Este mesmo autor, obteve uma absorção máxima de potássio na parte aérea da cultivar Vera de 519,8 mg, valores esses, superiores ao deste experimento.

As quantidades de potássio absorvidas encontradas neste experimento na planta inteira, são menores que os valores encontrados por Furlani (1995), que obteve 869 e $1105 \mathrm{mg}$ de potássio para as cultivares Marisa e Verônica, respectivamente.

As quantidades de potássio nas raízes, diferiram estatisticamente em função das soluções nutritivas e das posições das plantas de alface nos tubos ou colunas (Tabela 7).

Para as soluções nutritivas, o tratamento com menor dose de cálcio resultou nos maiores valores de acúmulo de potássio nas raízes, mas não diferiram estatisticamente da solução nutritiva completa e da com maior dose de cálcio. $\mathrm{O}$ acúmulo de potássio nas raízes foi maior nas plantas da posição superior, tendo se mostrado estatisticamente diferente da posição inferior. Na posição intermediária, o tratamento completo diferiu estatisticamente do tratamento com menor dose de cálcio. 
Tabela 5. Acúmulo de nitrogênio no material seco da parte aérea e nas raízes das plantas de alface cv.Vera, cultivadas em soluções nutritivas em função das concentrações de cálcio e da posição no tubo vertical.

\begin{tabular}{|c|c|c|c|c|}
\hline \multicolumn{5}{|c|}{ Concentração de cálcio, $\mathrm{mmol} \mathrm{L}^{-1}$} \\
\hline & 8,55 & 5,70 & 2,85 & \\
\hline Posição & \multicolumn{3}{|c|}{ mg por planta $(*)$} & Médias $^{(1)}$ \\
\hline \multicolumn{5}{|c|}{ Nitrogênio da parte aérea } \\
\hline Superior & $66,49 \mathrm{~B} \mathrm{a}$ & $106,51 \mathrm{AB}$ a & $135,33 \mathrm{~A} \mathrm{a}$ & $102,78 \mathrm{~A}$ \\
\hline Mediana & $76,14 \mathrm{~A} \mathrm{a}$ & $118,83 \mathrm{~A} \mathrm{a}$ & $69,03 \mathrm{~A} \mathrm{~b}$ & $88,00 \mathrm{~A}$ \\
\hline Inferior & $66,40 \mathrm{~A} \mathrm{a}$ & $76,66 \mathrm{~A}$ a & $84,46 \mathrm{~A} \mathrm{~b}$ & $75,84 \mathrm{~A}$ \\
\hline Médias $^{(2)}$ & $69,68 \mathrm{~A}$ & $100,66 \mathrm{~A}$ & $96,27 \mathrm{~A}$ & 88,87 \\
\hline \multicolumn{5}{|c|}{ Nitrogênio das raízes } \\
\hline Superior & $22,54 \mathrm{~A} \mathrm{a}$ & $40,15 \mathrm{~A}$ a & $36,64 \mathrm{~A} \mathrm{a}$ & $33,11 \mathrm{~A}$ \\
\hline Mediana & $25,97 \mathrm{AB}$ a & $32,91 \mathrm{~A} a b$ & $13,21 \mathrm{~B} \mathrm{~b}$ & $24,03 \mathrm{AB}$ \\
\hline Inferior & $18,22 \mathrm{~A} \mathrm{a}$ & $18,80 \mathrm{~A} \mathrm{~b}$ & $25,43 \mathrm{~A} \mathrm{ab}$ & $20,82 \mathrm{~B}$ \\
\hline Médias $^{(2)}$ & $22,24 \mathrm{~A}$ & $30,62 \mathrm{~A}$ & $25,09 \mathrm{~A}$ & 25,98 \\
\hline
\end{tabular}

$\left(^{*}\right)$ Valores seguidos por letras iguais não diferem estatísticamente a $5 \%$ pelo teste de Tukey para a comparação entre o fator posição ${ }^{(1)}$ e o fator concentração de cálcio ${ }^{(2)}$. Para a interação concentração de cálcio e posição, letras minúsculas comparam as médias entre as posições dentro de uma mesma concentração de cálcio e letras maiúsculas comparam as médias entre as concentrações de cálcio dentro de uma mesma posição no tubo vertical. 
Tabela 6. Acúmulo de fósforo no material seco da parte aérea e nas raízes das plantas de alface cv. Vera cultivadas em soluções nutritivas em função das concentrações de cálcio e da posição no tubo vertical.

\begin{tabular}{|c|c|c|c|c|}
\hline \multicolumn{5}{|c|}{ Concentração de cálcio, $\mathrm{mmol} \mathrm{L}^{-1}$} \\
\hline & 8,55 & 5,70 & 2,85 & \multirow[b]{2}{*}{ Médias $^{(1)}$} \\
\hline Posição & \multicolumn{3}{|c|}{$\begin{array}{l}\text { mg por planta }\left({ }^{*}\right) \\
\text { Fósforo da parte aérea }\end{array}$} & \\
\hline Superior & 17,20 & 18,89 & 24,58 & $20,22 \mathrm{~A}$ \\
\hline Mediana & 16,01 & 19,11 & 13,01 & $16,05 \mathrm{~A}$ \\
\hline Inferior & 13,94 & 18,49 & 16,46 & $16,30 \mathrm{~A}$ \\
\hline \multirow[t]{2}{*}{ Médias $^{(2)}$} & $15,71 \mathrm{~A}$ & $18,83 \mathrm{~A}$ & $18,02 \mathrm{~A}$ & 17,52 \\
\hline & \multicolumn{3}{|c|}{ Fósforo das raízes } & \\
\hline Superior & $7,48 \mathrm{~A}$ a & $9,28 \mathrm{~A} \mathrm{a}$ & $8,75 \mathrm{~A} \mathrm{a}$ & $8,51 \mathrm{~A}$ \\
\hline Mediana & $6,64 \mathrm{AB} a$ & $8,95 \mathrm{~A}$ ab & $3,56 \mathrm{~B} \mathrm{~b}$ & $6,38 \mathrm{AB}$ \\
\hline Inferior & $4,96 \mathrm{~A} \mathrm{a}$ & $4,62 \mathrm{~A} \mathrm{~b}$ & $7,36 \mathrm{~A} a b$ & $5,65 \mathrm{~B}$ \\
\hline Médias $^{(2)}$ & $6,36 \mathrm{~A}$ & $7,62 \mathrm{~A}$ & $6,55 \mathrm{~A}$ & 6,84 \\
\hline
\end{tabular}

$\left(^{*}\right)$ Valores seguidos por letras iguais não diferem estatísticamente a $5 \%$ pelo teste de Tukey para a comparação entre o fator posição $0^{(1)}$ e o fator concentração de cálcio ${ }^{(2)}$. Para a interação concentração de cálcio e posição, letras minúsculas comparam as médias entre as posições dentro de uma mesma concentração de cálcio e letras maiúsculas comparam as médias entre as concentrações de cálcio dentro de uma mesma posição no tubo vertical. 
Tabela 7. Acúmulo de potássio no material seco da parte aérea e nas raízes das plantas de alface cv. Vera cultivadas em soluções nutritivas em função das concentrações de cálcio e da posição no tubo vertical.

\begin{tabular}{|c|c|c|c|c|}
\hline \multicolumn{5}{|c|}{ Concentração de cálcio, mmol L ${ }^{-1}$} \\
\hline & 8,55 & 5,70 & 2,85 & \multirow[b]{2}{*}{ Médias $^{(1)}$} \\
\hline Posição & \multicolumn{3}{|c|}{$\begin{array}{c}\text { mg por planta }\left({ }^{*}\right) \\
\text { Potássio da parte aérea }\end{array}$} & \\
\hline Superior & $164,87 \mathrm{~B} \mathrm{a}$ & $213,93 \mathrm{AB}$ a & $307,90 \mathrm{~A} \mathrm{a}$ & $228,90 \mathrm{~A}$ \\
\hline Mediana & $153,72 \mathrm{~A}$ a & $217,57 \mathrm{~A} \mathrm{a}$ & $145,79 \mathrm{~A} \mathrm{~b}$ & $172,36 \mathrm{AB}$ \\
\hline Inferior & $138,50 \mathrm{~A} \mathrm{a}$ & $186,51 \mathrm{~A} \mathrm{a}$ & $165,79 \mathrm{~A} \mathrm{~b}$ & $163,60 \mathrm{~B}$ \\
\hline Médias $^{(2)}$ & $152,36 \mathrm{~A}$ & $206,00 \mathrm{~A}$ & $206,49 \mathrm{~A}$ & 188,29 \\
\hline \multicolumn{5}{|c|}{ Potássio das raízes } \\
\hline $\begin{array}{l}\text { Superior } \\
\text { Mediana }\end{array}$ & $\begin{array}{l}29,15 \mathrm{~A} \mathrm{a} \\
35,13 \mathrm{AB} \mathrm{a}\end{array}$ & $\begin{array}{l}41,17 \mathrm{~A} \mathrm{a} \\
40,04 \mathrm{~A} \mathrm{a}\end{array}$ & $\begin{array}{l}48,88 \mathrm{~A} \mathrm{a} \\
16,86 \mathrm{~B} \mathrm{~b}\end{array}$ & $\begin{array}{l}39,73 \mathrm{~A} \\
30,68 \mathrm{AB}\end{array}$ \\
\hline Inferior & $18,70 \mathrm{~A} \mathrm{a}$ & $20,29 \mathrm{~A} \mathrm{a}$ & $36,49 \mathrm{~A} a b$ & $25,16 \mathrm{~B}$ \\
\hline Médias $^{(2)}$ & $27,66 \mathrm{~A}$ & $33,84 \mathrm{~A}$ & $34,08 \mathrm{~A}$ & 31,86 \\
\hline
\end{tabular}

$\left(^{*}\right)$ Valores seguidos por letras iguais não diferem estatísticamente a $5 \%$ pelo teste de Tukey para a comparação entre o fator posição ${ }^{(1)}$ e $o$ fator concentração de cálcio ${ }^{(2)}$. Para a interação concentração de cálcio e posição, letras minúsculas comparam as médias entre as posições dentro de uma mesma concentração de cálcio e letras maiúsculas comparam as médias entre as concentrações de cálcio dentro de uma mesma posição no tubo vertical. 


\subsubsection{Cálcio}

Os resultados referentes aos acúmulos de cálcio, magnésio e de enxofre no material seco da parte aérea e raizes das plantas em função dos tratamentos encontram-se nas tabelas 8,9 e 10 .

As interações entre as concentrações de cálcio na solução e as posições das plantas nos tubos não foram significativas para o acúmulo de cálcio na parte aérea, mas foram significativas para as plantas para o acúmulo de cálcio nas raizes. Na parte aérea, as maiores médias na quantidade de cálcio foram encontradas para as plantas da posição superior diferindo estatisticamente das demais posições.

Ruschel (1998) obteve a menor concentração de cálcio na parte aérea de $12,8 \mathrm{~g}$ $\mathrm{kg}^{-1}$, sendo maior que a encontrada por Costa et al. (1997), de 7,9 $\mathrm{g} \mathrm{kg}^{-1}$ para a cultivar Babá, inferior ao deste experimento como o tratamento de $5,7 \mathrm{mmol} \mathrm{L}^{-1}$ de cálcio que obteve $10,40 \mathrm{~g} \mathrm{~kg}^{-1}$.

Os resultados foram superiores aos encontrados por Faquin et al. (1996) de 12,9 $\mathrm{g} \mathrm{kg}^{-1}$, sendo que neste experimento foram encontrados valores maiores na posição superior $\left(47,10 \mathrm{~g} \mathrm{~kg}^{-1}\right)$. As concentrações encontradas na parte aérea estão acima da faixa de concentração considerada como adequada por Reuter \& Robinson (1997), o que indica uma faixa de 14,0 a $15,0 \mathrm{~g} \mathrm{~kg}^{-1}$ de cálcio.

Ruschel (1998) encontrou quantidades de cálcio absorvido que variaram entre 65,9 e $111,4 \mathrm{mg}$ na parte aérea e de 66,2 e $113,0 \mathrm{mg}$ na planta inteira. Para a cultivar Marisa, a quantidade de cálcio absorvida variou entre 85,2 e $95,1 \mathrm{mg}$ na parte aérea e 85,9 e 96,4 mg na planta inteira. No presente experimento, os valores de cálcio estavam em uma amplitude de 30,95 até 47,10 mg na parte aérea.

Os resultados da quantidade de cálcio absorvido pela parte aérea são menores que os de Furlani (1995), que obteve $145 \mathrm{mg}$ de cálcio para a cultivar Marisa e similares aos de Costa et al.(1997), que obtiveram 47,9 mg de cálcio para a cultivar Babá. 
Quanto às quantidades de cálcio nas raizes, houve diferenças significativas para as interações soluções nutritivas $\mathrm{x}$ posições. As quantidades de cálcio acumuladas nas raizes não diferiram para as três soluções nutritivas, para as plantas das posições superiores. Entretanto, foram significativamente diferentes para as plantas das outras posições. (Tabela 8)

\subsubsection{Magnésio}

A quantidade de magnésio acumulada na parte aérea das plantas, não variou significativamente em função das soluções nutritivas. Porém, as médias de magnésio na parte aérea das plantas das posições superiores diferiram estatisticamente das médias encontradas nas posições intermediária e inferior. (Tabela 9)

As quantidades de magnésio nas raízes diferiram significativamente em função das soluções nutritivas e posições das plantas. A solução nutritiva com menor dose de cálcio, juntamente com a solução completa, resultaram nas maiores quantidades de magnésio nas raizes das plantas da posição superior, diferindo estatisticamente da solução com maior dose de cálcio. (Tabela 9)

Esse comportamento decrescente, com o aumento das doses, pode ser explicado

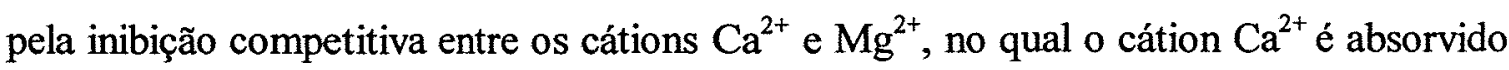
preferencialmente (Marschner, 1995).

As concentrações de magnésio na parte aérea estão dentro da faixa de concentração considerada como adequada por Reuter \& Robinson (1997), que indica uma faixa de 3 a $5 \mathrm{~g} \mathrm{~kg}^{-1}$ de magnésio sendo que neste experimento na solução com menor dose de cálcio é de $4,71 \mathrm{~g} \mathrm{~kg}^{-1}$. 


\subsubsection{Enxofre}

O acúmulo de enxofre no material seco da parte aérea e das raízes da alface, cultivar Vera, estão apresentados na tabela 10. Houve diferença estatística entre as posições, sendo que as plantas da posição superior apresentaram a maior média de enxofre na parte aérea, diferindo estatisticamente das demais posições.

Ruschel (1998) obteve a concentração máxima de enxofre na parte aérea de 3,56 $\mathrm{g} \mathrm{kg}^{-1}$, para a cultivar Marisa, na solução nutritiva, sendo esse valor superior à concentração máxima obtida nesse experimento que é de $2,93 \mathrm{~g} \mathrm{~kg}^{-1}$ para a solução com a menor dose de cálcio. As concentrações de enxofre na parte aérea estão dentro da faixa de concentração considerada como adequada por Reuter \& Robinson (1997), que indica uma faixa de 3 a $4 \mathrm{~g} \mathrm{~kg}^{-1}$ de enxofre.

Ruschel (1998) obteve no ponto de absorção máxima de enxofre 22,3 mg na parte aérea da cultivar Vera. Costa et al. (1997) obtiveram resultados da quantidade de enxofre absorvido pela parte aérea similares ao deste experimento $(11,5 \mathrm{mg})$.

Ruschel (1998) ainda encontrou uma quantidade máxima de enxofre na planta inteira de $24,7 \mathrm{mg}$, sendo que no presente experimento, a quantidade máxima foi de 18 mg na solução com menor dose de cálcio.

Estes resultados da quantidade de enxofre absorvido pela planta inteira são similares aos de Faquin et al.(1996) que obtiveram $18,4 \mathrm{mg}$ de enxofre para a cultivar Verônica. As médias das quantidades de enxofre nas raízes diferiram estatisticamente para as soluções nutritivas, tendo sido mais elevada para a solução com menor dose de cálcio. As médias não diferiram estatisticamente quanto à posição das plantas nos tubos. (Tabela 10) 
Tabela 8. Acúmulo de cálcio no material seco na parte aérea e nas raízes das plantas de alface cv. Vera cultivadas em soluções nutritivas em função das concentrações de cálcio e da posição no tubo vertical.

\begin{tabular}{|c|c|c|c|c|}
\hline \multicolumn{5}{|c|}{ Concentração de cálcio, $\mathrm{mmol} \mathrm{L}^{-1}$} \\
\hline & 8,55 & 5,70 & 2,85 & \multirow[b]{2}{*}{ Médias $^{(1)}$} \\
\hline Posição & \multicolumn{3}{|c|}{$\begin{array}{c}\left.\text { mg por planta( }{ }^{*}\right) \\
\text { Cálcio da parte aérea }\end{array}$} & \\
\hline Superior & 55,70 & 40,31 & 45,28 & $47,10 \mathrm{~A}$ \\
\hline Mediana & 37,19 & 40,17 & 21,00 & $32,79 \mathrm{~B}$ \\
\hline Inferior & 29,53 & 36,46 & 26,86 & $30,95 \mathrm{~B}$ \\
\hline \multirow[t]{2}{*}{ Médias $^{(2)}$} & $40,81 \mathrm{~A}$ & $38,98 \mathrm{~A}$ & $31,05 \mathrm{~A}$ & 36,94 \\
\hline & \multicolumn{3}{|c|}{ Cálcio das raízes } & \\
\hline $\begin{array}{l}\text { Superior } \\
\text { Mediana }\end{array}$ & $\begin{array}{l}5,37 \mathrm{~A} \mathrm{ab} \\
6,52 \mathrm{~A} \mathrm{a}\end{array}$ & $\begin{array}{l}5,78 \mathrm{~A} \mathrm{a} \\
4,31 \mathrm{AB} \text { a }\end{array}$ & $\begin{array}{l}4,10 \mathrm{~A} \mathrm{a} \\
1,29 \mathrm{~B} \mathrm{a}\end{array}$ & $\begin{array}{l}5,08 \mathrm{~A} \\
4,04 \mathrm{AB}\end{array}$ \\
\hline Inferior & $3,08 \mathrm{~A} \mathrm{~b}$ & $3,59 \mathrm{~A} \mathrm{a}$ & $3,45 \mathrm{~A} \mathrm{a}$ & $3,37 \mathrm{~B}$ \\
\hline Médias $^{(2)}$ & $4,99 \mathrm{~A}$ & $4,56 \mathrm{~A}$ & $2,95 \mathrm{~A}$ & 4,16 \\
\hline
\end{tabular}

$\left(^{*}\right)$ Valores seguidos por letras iguais não diferem estatísticamente a $5 \%$ pelo teste de Tukey para a comparação entre o fator posição ${ }^{(1)}$ e o fator concentração de cálcio ${ }^{(2)}$. Para a interação concentração de cálcio e posição, letras minúsculas comparam as médias entre as posições dentro de uma mesma concentração de cálcio e letras maiúsculas comparam as médias entre as concentraçães de cálcio dentro de uma mesma posição no tubo vertical. 
Tabela 9. Acúmulo de magnésio no material seco na parte aérea e nas raízes das plantas de alface cv. Vera cultivadas em soluções nutritivas em função das concentrações de cálcio e da posição no tubo vertical.

\begin{tabular}{|c|c|c|c|c|}
\hline \multicolumn{5}{|c|}{ Concentração de cálcio, $\mathrm{mmol} \mathrm{L}^{-1}$} \\
\hline & 8,55 & 5,70 & 2,85 & \multirow[b]{2}{*}{ Médias $^{(1)}$} \\
\hline Posição & \multicolumn{3}{|c|}{$\begin{array}{c}\text { mg por planta }\left({ }^{*}\right) \\
\text { Magnésio da parte aérea }\end{array}$} & \\
\hline Superior & 12,93 & 13,18 & 18,23 & $14,78 \mathrm{~A}$ \\
\hline Mediana & 9,63 & 13,99 & 8,69 & $10,77 \mathrm{~B}$ \\
\hline Inferior & 8,79 & 11,69 & 11,31 & $10,59 \mathrm{~B}$ \\
\hline \multirow[t]{2}{*}{ Médias $^{(2)}$} & $10,45 \mathrm{~A}$ & $12,95 \mathrm{~A}$ & $12,74 \mathrm{~A}$ & 12,05 \\
\hline & \multicolumn{3}{|c|}{ Magnésio das raízes } & \\
\hline $\begin{array}{l}\text { Superior } \\
\text { Mediana }\end{array}$ & $\begin{array}{l}1,57 \mathrm{~B} \mathrm{a} \\
1,80 \mathrm{~A} \mathrm{a}\end{array}$ & $\begin{array}{l}3,21 \mathrm{~A} \mathrm{a} \\
2,50 \mathrm{~A} \mathrm{ab}\end{array}$ & $\begin{array}{l}3,60 \mathrm{~A} \mathrm{a} \\
1,36 \mathrm{~A} \mathrm{~b}\end{array}$ & $\begin{array}{l}2,79 \mathrm{~A} \\
1,89 \mathrm{~B}\end{array}$ \\
\hline Inferior & $1,04 \mathrm{~A} \mathrm{a}$ & $1,25 \mathrm{~A} \mathrm{~b}$ & $2,24 \mathrm{~A} \mathrm{ab}$ & $1,51 \mathrm{~B}$ \\
\hline Médias $^{(2)}$ & $1,47 \mathrm{~A}$ & $2,32 \mathrm{~A}$ & $2,40 \mathrm{~A}$ & 2,06 \\
\hline
\end{tabular}

$\left(^{*}\right)$ Valores seguidos por letras iguais não diferem estatísticamente a $5 \%$ pelo teste de Tukey para a comparação entre o fator posição ${ }^{(1)}$ e o fator concentração de cálcio ${ }^{(2)}$. Para a interação concentração de cálcio e posição, letras minúsculas comparam as médias entre as posições dentro de uma mesma concentração de cálcio e letras maiúsculas comparam as médias entre as concentrações de cálcio dentro de uma mesma posição no tubo vertical. 
Tabela 10. Acúmulo de enxofre no material seco na parte aérea e nas raízes das plantas de alface cv. Vera cultivadas em soluções nutritivas em função das concentrações de cálcio e da posição no tubo vertical.

\begin{tabular}{|c|c|c|c|c|}
\hline \multicolumn{5}{|c|}{ Concentração de cálcio, $\mathrm{mmol} \mathrm{L}^{-1}$} \\
\hline & 8,55 & 5,70 & 2,85 & \multirow[b]{2}{*}{ Médias $^{(1)}$} \\
\hline Posição & \multicolumn{3}{|c|}{$\begin{array}{c}\text { mg por planta }\left({ }^{*}\right) \\
\text { Enxofre da parte aérea }\end{array}$} & \\
\hline Superior & 11,49 & 9,40 & 11,34 & $10,74 \mathrm{~A}$ \\
\hline Mediana & 6,76 & 8,53 & 7,85 & 7,71 B \\
\hline Inferior & 6,46 & 8,58 & 8,63 & $7,89 \mathrm{~B}$ \\
\hline Médias ${ }^{(2)}$ & $8,24 \mathrm{~A}$ & $8,84 \mathrm{~A}$ & $9,27 \mathrm{~A}$ & 8,78 \\
\hline \multicolumn{5}{|c|}{ Enxofre das raízes } \\
\hline $\begin{array}{l}\text { Superior } \\
\text { Mediana }\end{array}$ & $\begin{array}{l}2,18 \mathrm{~B} \mathrm{a} \\
2,61 \mathrm{~A} \mathrm{a}\end{array}$ & $\begin{array}{l}2,98 \mathrm{~B} \mathrm{a} \\
3,37 \mathrm{~A} \mathrm{a}\end{array}$ & $\begin{array}{l}6,58 \mathrm{~A} \mathrm{a} \\
2,62 \mathrm{~A} \mathrm{~b}\end{array}$ & $\begin{array}{l}3,91 \mathrm{~A} \\
2,87 \mathrm{~A}\end{array}$ \\
\hline Inferior & $1,49 \mathrm{~B} \mathrm{a}$ & $1,49 \mathrm{~B} \mathrm{a}$ & $4,99 \mathrm{~A} \mathrm{a}$ & $2,66 \mathrm{~A}$ \\
\hline Médias $^{(2)}$ & $2,09 \mathrm{~B}$ & $2,61 \mathrm{AB}$ & $4,73 \mathrm{~A}$ & 3,15 \\
\hline
\end{tabular}

$\left(^{*}\right)$ Valores seguidos por letras iguais não diferem estatísticamente a $5 \%$ pelo teste de Tukey para a comparação entre o fator posição ${ }^{(1)}$ e o fator concentração de cálcio ${ }^{(2)}$. Para a interação concentração de cálcio e posição, letras minúsculas comparam as médias entre as posições dentro de uma mesma concentração de cálcio e letras maiúsculas comparam as médias entre as concentrações de cálcio dentro de uma mesma posição no tubo vertical. 


\subsubsection{Acúmulo de sódio}

Os resultados referentes ao acúmulo de sódio e micronutrientes em função das soluções estudadas e das posições das plantas nos tubos encontram-se nas tabelas 11 a 16. A análise da variância das quantidades de sódio na parte aérea mostrou interação significativa entre soluções x posições (Tabela 11).

Quanto às soluções nutritivas, o acúmulo de sódio na parte aérea foi menor na solução com maior dose de cálcio e foi maior na solução com menor dose de cálcio. Quanto às posições das plantas, o acúmulo de sódio foi maior nas plantas da posição superior, considerada estatisticamente diferente da posição intermediária .

As médias das quantidades de sódio nas raizes diferiram estatisticamente entre as soluções nutritivas, sendo que a solução nutritiva com menor dose de cálcio resultou nas maiores médias, diferindo estatisticamente das soluções completa e com maior dose de cálcio. A posição superior diferiu significativamente das demais posições, sendo que no tratamento completo a posição superior diferiu estatisticamente da posição inferior.

$\mathrm{O}$ acúmulo decrescente de $\mathrm{Na}$ nas plantas com o aumento da concentração de cálcio na solução nutritiva, pode ser explicado pelo efeito competitivo entre os cátions $\mathrm{Ca}^{2+} \mathrm{e} \mathrm{Na}^{+}$. 
Tabela 11. Acúmulo de sódio no material seco da parte aérea e nas raízes das plantas de alface cv. Vera cultivadas em soluções nutritivas em função de três concentrações de cálcio e da posição no tubo vertical.

\begin{tabular}{|c|c|c|c|c|}
\hline \multicolumn{5}{|c|}{ Concentração de cálcio, mmol L ${ }^{-1}$} \\
\hline & 8,55 & 5,70 & 2,85 & \\
\hline Posição & \multicolumn{3}{|c|}{$\begin{array}{l}\text { mg por planta(*) } \\
\text { Sódio da parte aérea }\end{array}$} & Médias $^{(1)}$ \\
\hline Superior & $4,58 \mathrm{~B} \mathrm{a}$ & $5,33 \mathrm{~B} \mathrm{a}$ & $28,64 \mathrm{~A} \mathrm{a}$ & $12,85 \mathrm{~A}$ \\
\hline Mediana & $3,53 \mathrm{~B} \mathrm{a}$ & $4,53 \mathrm{~B}$ a & $14,50 \mathrm{~A} \mathrm{~b}$ & $7,52 \mathrm{~B}$ \\
\hline Inferior & $3,18 \mathrm{~B} \mathrm{a}$ & $5,87 \mathrm{~B} \mathrm{a}$ & $19,57 \mathrm{~A} \mathrm{~b}$ & $9,54 \mathrm{AB}$ \\
\hline \multirow[t]{2}{*}{ Médias $^{(2)}$} & $3,76 \mathrm{~B}$ & $5,24 \mathrm{~B}$ & $20,90 \mathrm{~A}$ & 9,97 \\
\hline & \multicolumn{3}{|c|}{ Sódio das raízes } & \\
\hline $\begin{array}{l}\text { Superior } \\
\text { Mediana }\end{array}$ & $\begin{array}{l}1,95 \mathrm{C} \mathrm{a} \\
3,12 \mathrm{~A} \mathrm{a}\end{array}$ & $\begin{array}{l}8,19 \mathrm{~B} \mathrm{a} \\
6,22 \mathrm{~A} \mathrm{ab}\end{array}$ & $\begin{array}{r}12,77 \mathrm{~A} \mathrm{a} \\
4,94 \mathrm{~A} \mathrm{~b}\end{array}$ & $\begin{array}{l}7,63 \mathrm{~A} \\
4,76 \mathrm{~B}\end{array}$ \\
\hline Inferior & $1,20 \mathrm{~B} \mathrm{a}$ & $2,21 \mathrm{~B} \mathrm{~b}$ & $9,53 \mathrm{~A} \mathrm{a}$ & $4,32 \mathrm{~B}$ \\
\hline Médias $^{(2)}$ & $2,09 \mathrm{~B}$ & $5,54 \mathrm{AB}$ & $9,08 \mathrm{~A}$ & 5,57 \\
\hline
\end{tabular}

$\left(^{*}\right)$ Valores seguidos por letras iguais não diferem estatísticamente a $5 \%$ pelo teste de Tukey para a comparação entre o fator posição ${ }^{(1)}$ e o fator concentração de cálcio ${ }^{(2)}$. Para a interação concentração de cálcio e posição, letras minúsculas comparam as médias entre as posições dentro de uma mesma concentração de cálcio e letras maiúsculas comparam as médias entre as concentrações de cálcio dentro de uma mesma posição no tubo vertical. 


\subsection{Acúmulo de micronutrientes}

\subsubsection{Boro}

As médias das quantidades de boro na parte aérea diferiram quanto às soluções nutritivas e posições das plantas nos tubos. As soluções nutritivas completa, com menor e maior dose de cálcio na parte aérea, não diferiram estatisticamente (Tabela 12).

Houve um efeito significativo da posição das plantas nos tubos sobre as quantidades de boro da parte aérea. As maiores quantidades de boro foram acumuladas nas plantas da parte superior, que foram estatisticamente diferentes das demais posições. $\mathrm{Na}$ solução com menor dose de cálcio, a posição superior diferiu estatisticamente das demais posições. (Tabela 12)

Para as quantidades de boro nas raízes, houve interação entre soluções nutritivas e posições, sendo que a solução nutritiva completa resultou em maior acúmulo de boro nas raizes, estatisticamente diferentes da solução com menor e maior dose de cálcio. As médias das posições não diferiram estatisticamente entre si (Tabela 12).

Garcia (1988) obtiveram resultados das quantidades de boro absorvidas por plantas de alface, cultivares Brasil 48 e Clause's Aurélia de 82,7 $\mu \mathrm{g}$ por planta e 119,7 $\mu \mathrm{g}$ por planta respectivamente. Esses resultados foram similares às quantidades obtidas em plantas de alface nas soluções nutritivas do presente experimento, com valores de 45,6 a $166,4 \mu \mathrm{g}$ por planta na solução nutritiva com menor dose de cálcio na parte aérea. 


\subsubsection{Cobre}

Quanto ao acúmulo de cobre, houve significância para as quantidades de cobre na parte aérea em relação às posições (Tabela 13). A posição superior das plantas nos tubos resultou em maior acúmulo de cobre na parte aérea, diferindo estatisticamente da posição intermediária .

Garcia (1988) encontraram quantidades de cobre na parte aérea para as cultivares

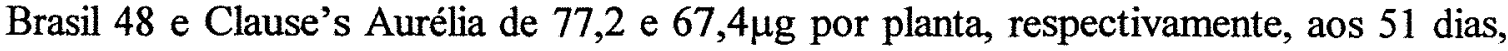
sendo similares aos obtidos nas soluções nutritivas deste experimento.

As médias das quantidades de cobre nas raízes, as soluções nutritivas completa diferiram estatisticamente da solução nutritiva com maior dose de cálcio, que apresentou as menores médias, aparecendo aqui o efeito competitivo do cálcio sobre a absorção do cobre $\left(\mathrm{Cu}^{2+}\right)$. As posições não tiveram efeito estatisticamente significativo nas médias de cobre nas raízes, porém, os dados foram variáveis e inconsistentes. (Tabela 13).

\subsubsection{Ferro}

Para as médias de ferro na parte aérea, houve interação significativa para as soluções e as posições. A quantidade de ferro acumulada na parte aérea foi maior nas plantas da posição superior na solução com menor dose de cálcio. (Tabela 14).

Para as raízes, houve interação significativa entre as médias obtidas para diferentes soluções e posições. Porém os dados foram variáveis e inconsistentes.(Tabela $14)$.

Na menor concentração de cálcio as plantas apresentaram maior acúmulo de ferro na posição superior. Na solução completa, não houve diferença entre a posição inferior e intermediária.

Com relação à posição das plantas nos tubos, o acúmulo de ferro nas raízes foi maior na posição superior, diferindo estatisticamente da posição inferior. As quantidades 
de ferro encontradas nas raízes geralmente são bem elevadas, pois o ferro complexado aderido às paredes externas das células das raízes, não são retirados na lavagem que se procede para a análise química.

Garcia (1988) obtiveram resultados de 2146,1 e $2848,8 \mu \mathrm{g}$ por planta, para as cultivares Brasil 48 e Clause's Aurelia, respectivamente, sendo superiores aos encontrados nesse experimento que foi encontrado nos valores 643 e $1587 \mu \mathrm{g}$ por planta.

As diferenças observadas nos resultados desses autores em relação aos deste experimento poderiam ser devidos a: cultivares diferentes, duração do experimento, sistema de produção diferente hidroponia / aeroponia, volume de solução nutritiva utilizada por planta e época do ano. 
Tabela 12. Acúmulo de boro na parte aérea e nas raízes das plantas de alface cv. Vera cultivadas em soluções nutritivas em função das concentrações de cálcio e da posição no tubo vertical.

\begin{tabular}{|c|c|c|c|c|}
\hline \multicolumn{5}{|c|}{ Concentração de cálcio, $\mathrm{mmol} \mathrm{L}^{-1}$} \\
\hline & 8,55 & 5,70 & 2,85 & \\
\hline Posição & \multicolumn{3}{|c|}{$\begin{array}{c}\mu \mathrm{g} \text { por planta }\left(^{*}\right) \\
\text { Boro da parte aérea }\end{array}$} & Médias $^{(1)}$ \\
\hline Superior & $95,19 \mathrm{~B}$ a & $116,62 \mathrm{AB} a b$ & $166,41 \mathrm{~A} \mathrm{a}$ & $126,07 \mathrm{~A}$ \\
\hline Mediana & $74,86 \mathrm{~B}$ a & $144,57 \mathrm{~A}$ a & $45,63 \mathrm{~B} \mathrm{~b}$ & $88,35 \mathrm{~B}$ \\
\hline Inferior & $76,32 \mathrm{~A} \mathrm{a}$ & $80,50 \mathrm{~A} \mathrm{~b}$ & $55,76 \mathrm{Ab}$ & $70,86 \mathrm{~B}$ \\
\hline \multirow[t]{2}{*}{ Médias $^{(2)}$} & $82,12 \mathrm{~A}$ & $113,90 \mathrm{~A}$ & $89,27 \mathrm{~A}$ & 95,10 \\
\hline & \multicolumn{3}{|c|}{ Boro das raízes } & \\
\hline $\begin{array}{l}\text { Superior } \\
\text { Mediana }\end{array}$ & $\begin{array}{l}23,24 \mathrm{~B} \mathrm{a} \\
42,55 \mathrm{AB} \text { a }\end{array}$ & $\begin{array}{l}60,13 \mathrm{~A} \mathrm{a} \\
63,44 \mathrm{~A} \mathrm{a}\end{array}$ & $\begin{array}{l}36,64 \mathrm{AB} a \\
23,75 \mathrm{~B} \mathrm{a}\end{array}$ & $\begin{array}{l}40,00 \mathrm{~A} \\
43,25 \mathrm{~A}\end{array}$ \\
\hline Inferior & $29,00 \mathrm{~A} \mathrm{a}$ & $39,02 \mathrm{~A} \mathrm{a}$ & $46,35 \mathrm{~A} \mathrm{a}$ & $38,12 \mathrm{~A}$ \\
\hline Médias $^{(2)}$ & $31,60 \mathrm{~B}$ & $54,20 \mathrm{~A}$ & $35,58 \mathrm{AB}$ & 40,46 \\
\hline
\end{tabular}

(*) Valores seguidos por letras iguais não diferem estatísticamente a $5 \%$ pelo teste de Tukey para a comparação entre o fator posição ${ }^{(1)} \mathrm{e} o$ fator concentração de cálcio ${ }^{(2)}$. Para a interação concentração de cálcio e posição, letras minúsculas comparam as médias entre as posições dentro de uma mesma concentração de cálcio e letras maiúsculas comparam as médias entre as concentrações de cálcio dentro de uma mesma posição no tubo vertical. 
Tabela 13. Acúmulo de cobre na parte aérea e nas raízes das plantas de alface cv. Vera cultivadas em soluções nutritivas em função das concentrações de cálcio e da posição no tubo vertical.

\begin{tabular}{|c|c|c|c|c|}
\hline \multicolumn{5}{|c|}{ Concentração de cálcio, mmol L-1 } \\
\hline & 8,55 & 5,70 & 2,85 & \multirow[b]{2}{*}{ Médias $^{(1)}$} \\
\hline Posição & \multicolumn{3}{|c|}{$\begin{array}{c}\mu \mathrm{g} \text { por planta }(*) \\
\text { Cobre da parte aérea }\end{array}$} & \\
\hline Superior & 48,94 & 45,52 & 67,73 & $54,06 \mathrm{~A}$ \\
\hline Mediana & 39,99 & 40,58 & 37,02 & $39,20 \mathrm{~B}$ \\
\hline Inferior & 36,56 & 54,05 & 45,15 & $45,26 \mathrm{AB}$ \\
\hline Médias $^{(2)}$ & $41,83 \mathrm{~A}$ & $46,72 \mathrm{~A}$ & $49,97 \mathrm{~A}$ & 46,17 \\
\hline \multicolumn{5}{|c|}{ Cobre das raizes } \\
\hline $\begin{array}{l}\text { Superior } \\
\text { Mediana }\end{array}$ & $\begin{array}{l}47,05 \mathrm{~B} \mathrm{a} \\
47,64 \mathrm{AB} \text { a }\end{array}$ & $\begin{array}{l}99,57 \mathrm{~A} \mathrm{a} \\
82,67 \mathrm{~A} \mathrm{ab}\end{array}$ & $\begin{array}{l}67,95 \mathrm{AB} \text { a } \\
22,54 \mathrm{~B} \mathrm{~b}\end{array}$ & $\begin{array}{l}71,52 \mathrm{~A} \\
50,95 \mathrm{~A}\end{array}$ \\
\hline Inferior & $35,53 \mathrm{~B} \mathrm{a}$ & $47,33 \mathrm{AB} \mathrm{b}$ & $88,25 \mathrm{~A} \mathrm{a}$ & $57,04 \mathrm{~A}$ \\
\hline Médias $^{(2)}$ & $43,41 \mathrm{~A}$ & $76,52 \mathrm{~A}$ & $59,58 \mathrm{~A}$ & 59,84 \\
\hline
\end{tabular}

(*) Valores seguidos por letras iguais não diferem estatísticamente a $5 \%$ pelo teste de Tukey para a comparação entre o fator posição ${ }^{(1)} \mathrm{e} o$ fator concentração de cálcio ${ }^{(2)}$. Para a interação concentração de cálcio e posição, letras minúsculas comparam as médias entre as posições dentro de uma mesma concentração de cálcio e letras maiúsculas comparam as médias entre as concentrações de cálcio dentro de uma mesma posição no tubo vertical. 
Tabela 14. Acúmulo de ferro da parte aérea e das raízes das plantas de alface cv. Vera cultivadas em soluções nutritivas em função das concentrações de cálcio e da posição no tubo vertical.

\begin{tabular}{|c|c|c|c|c|}
\hline \multicolumn{5}{|c|}{ Concentração de cálcio, $\mathrm{mmol} \mathrm{L}^{-1}$} \\
\hline & 8,55 & 5,70 & 2,85 & \multirow[b]{2}{*}{ Médias $^{(1)}$} \\
\hline Posição & \multicolumn{3}{|c|}{$\begin{array}{l}\mu \mathrm{g} \text { por planta }(*) \\
\text { Ferro da parte aérea }\end{array}$} & \\
\hline Superior & $869,3 \mathrm{~B} \mathrm{a}$ & $1245,0 \mathrm{AB}$ a & $1587,1 \mathrm{~A} \mathrm{a}$ & $1233,8 \mathrm{~A}$ \\
\hline Mediana & $812,0 \mathrm{AB}$ a & $1124,0 \mathrm{~A} \mathrm{ab}$ & $582,4 \mathrm{~B} \mathrm{~b}$ & $839,5 \mathrm{~B}$ \\
\hline Inferior & $642,9 \mathrm{~A} \mathrm{a}$ & $676,4 \mathrm{~A} \mathrm{~b}$ & $828,3 \mathrm{~A} \mathrm{~b}$ & $715,9 \mathrm{~B}$ \\
\hline \multirow[t]{2}{*}{ Médias $^{(2)}$} & $774,7 \mathrm{~A}$ & $1015,2 \mathrm{~A}$ & $999,2 \mathrm{~A}$ & 929,7 \\
\hline & \multicolumn{3}{|c|}{ Ferro das raízes } & \\
\hline Superior & $4397,9 \mathrm{~A} \mathrm{a}$ & $5526,6 \mathrm{~A} \mathrm{a}$ & $5393,5 \mathrm{~A}$ a & $5106,0 \mathrm{~A}$ \\
\hline Mediana & $3344,6 \mathrm{~B}$ a & $6011,2 \mathrm{~A} \mathrm{a}$ & $1771,3 \mathrm{~B} \mathrm{~b}$ & $3709,0 \mathrm{AB}$ \\
\hline Inferior & $2914,8 \mathrm{~A} \mathrm{a}$ & $2900,1 \mathrm{~A} \mathrm{~b}$ & $3040,9 \mathrm{~A} a b$ & $2951,9 \mathrm{~B}$ \\
\hline Médias $^{(2)}$ & $3552,4 \mathrm{~A}$ & $4812,6 \mathrm{~A}$ & $3401,9 \mathrm{~A}$ & 3922,3 \\
\hline
\end{tabular}

$\left(^{*}\right)$ Valores seguidos por letras iguais não diferem estatísticamente a $5 \%$ pelo teste de Tukey para a comparação entre o fator posição ${ }^{(1)}$ e o fator concentração de cálcio ${ }^{(2)}$. Para a interação concentração de cálcio e posição, letras minúsculas comparam as médias entre as posições dentro de uma mesma concentração de cálcio e letras maiúsculas comparam as médias entre as concentrações de cálcio dentro de uma mesma posição no tubo vertical. 


\subsubsection{Manganês}

As quantidades de manganês na parte aérea e raízes das plantas de alface, cultivar Vera, estão na tabela 15. A análise da variância da parte aérea mostrou efeito significativo da posição das plantas nos tubos.

As quantidades do nutriente manganês diferiram estatisticamente quanto à posição das plantas nos tubos, sendo que a posição superior resultou na maior média, diferindo estatisticamente da posição intermediária e inferior (Tabela 15).

Nas raízes, houve interação significativa para soluções $\mathrm{x}$ posições. A solução nutritiva com menor dose de cálcio resultou num maior acúmulo de manganês e, diferiu estatisticamente, da solução com maior dose de cálcio (Tabela 15).

O efeito de competição entre o cálcio e o manganês ficou evidente somente nas raízes, onde se observa redução na quantidade de $\mathrm{Mn}^{2+}$ acumulado em função do aumento na concentração de cálcio na solução. (Tabela 15)

Garcia (1988) obtiveram resultados de 455,8 e $103,7 \mu \mathrm{g}$ por planta para as cultivares Brasil 48 e Clause's Aurélia, respectivamente, aos 41 dias. Os resultados obtidos neste experimento, com a cultivar Vera, são inferiores aos encontrados para a cultivar Brasil 48 e, superiores aos da cultivar Clause's Aurélia. 


\subsubsection{Zinco}

A análise de variância para as quantidades de zinco na parte aérea mostrou diferenças significativas entre as médias para as posições. (Tabela 16). As plantas da posição superior apresentaram as maiores médias de acúmulo de zinco, que diferiram estatisticamente das posições intermediária e inferior .

Garcia (1988) encontraram quantidades de zinco na parte aérea de alface, aos 41 dias, da ordem de 455,7 e $343,7 \mu \mathrm{g}$ por planta, similares aos resultados encontrados neste experimento, para as plantas das posições superior e intermediária $(573,66$ e 300,81 $\mu \mathrm{g}$ por planta) da cultivar Vera no sistema de aeroponia.

A análise da variância das quantidades de zinco nas raízes, mostrou efeito da interação significativa entre as soluções nutritivas e as posições das plantas nos tubos ou colunas no sistema de aeroponia. $O$ acúmulo de zinco na parte aérea das plantas, na solução nutritiva com maior dose de cálcio não diferiu estatisticamente das soluções com menores doses de cálcio e completa. Maiores quantidades de zinco foram encontradas ns raízes das plantas da posição superior, comparadas às da posição inferior .(Tabela 16)

Mais uma vez, observa-se aqui o efeito das concentrações crescentes de cálcio na solução nutritiva sobre a quantidade de zinco $\left(\mathrm{Zn}^{2+}\right)$ absorvida pelas raízes. Quanto maior a concentração de cálcio na solução e na planta, menor a quantidade de zinco absorvida. 
Tabela 15. Acúmulo de manganês da parte aérea e das raízes das plantas de alface cv. Vera cultivadas em soluções nutritivas em função das concentrações de cálcio e da posição no tubo vertical.

\begin{tabular}{|c|c|c|c|c|}
\hline \multicolumn{5}{|c|}{ Concentração de cálcio, $\mathrm{mmol} \mathrm{L}^{-1}$} \\
\hline & 8,55 & 5,70 & 2,85 & \multirow[b]{2}{*}{ Médias $^{(1)}$} \\
\hline Posição & \multicolumn{3}{|c|}{$\begin{array}{c}\left.\mu \mathrm{g} \text { por planta } *^{*}\right) \\
\text { Manganês da parte aérea }\end{array}$} & \\
\hline Superior & 168,15 & 145,77 & 160,99 & $158,31 \mathrm{~A}$ \\
\hline Mediana & 127,46 & 133,02 & 79,90 & $113,46 \mathrm{~B}$ \\
\hline Inferior & 116,26 & 102,12 & 132,06 & $116,82 \mathrm{~B}$ \\
\hline Médias $^{(2)}$ & $137,29 \mathrm{~A}$ & $126,97 \mathrm{~A}$ & $124,32 \mathrm{~A}$ & 129,53 \\
\hline \multicolumn{5}{|c|}{ Manganês das raízes } \\
\hline Superior & $130,37 \mathrm{~B} \mathrm{a}$ & $307,40 \mathrm{~A} \mathrm{a}$ & $371,37 \mathrm{~A} \mathrm{a}$ & $269,71 \mathrm{~A}$ \\
\hline Mediana & $99,59 \mathrm{~B} \mathrm{a}$ & $250,54 \mathrm{~A} a b$ & $117,35 \mathrm{AB} b$ & $155,82 \mathrm{~B}$ \\
\hline Inferior & $72,62 \mathrm{~B} \mathrm{a}$ & $137,50 \mathrm{AB} b$ & $250,35 \mathrm{~A} a b$ & $153,49 \mathrm{~B}$ \\
\hline Médias $^{(2)}$ & $100,86 \mathrm{~B}$ & $231,81 \mathrm{~A}$ & $246,35 \mathrm{~A}$ & 193,01 \\
\hline
\end{tabular}

$\left({ }^{*}\right)$ Valores seguidos por letras iguais não diferem estatísticamente a $5 \%$ pelo teste de Tukey para a comparação entre o fator posição ${ }^{(1)}$ e o fator concentração de cálcio ${ }^{(2)}$. Para a interação concentração de cálcio e posição, letras minúsculas comparam as médias entre as posições dentro de uma mesma concentração de cálcio e letras maiúsculas comparam as médias entre as concentrações de cálcio dentro de uma mesma posição no tubo vertical. 
Tabela 16. Acúmulo de zinco da parte aérea e das raízes de plantas de alface cv. Vera cultivadas em soluções nutritivas em função de três concentrações de cálcio e posição no tubo vertical.

\begin{tabular}{|c|c|c|c|c|}
\hline \multicolumn{5}{|c|}{ Concentração de cálcio, $\mathrm{mmol} \mathrm{L}^{-1}$} \\
\hline & 8,55 & 5,70 & 2,85 & \\
\hline Posição & \multicolumn{3}{|c|}{$\begin{array}{l}\mu \mathrm{g} \text { por planta }\left(^{*}\right) \\
\text { Zinco da parte aérea }\end{array}$} & Médias $^{(1)}$ \\
\hline Superior & 530,72 & 549,78 & 640,49 & $573,66 \mathrm{~A}$ \\
\hline Mediana & 295,90 & 364,09 & 242,44 & $300,81 \mathrm{~B}$ \\
\hline Inferior & 185,66 & 175,26 & 152,83 & $171,25 \mathrm{C}$ \\
\hline \multirow[t]{2}{*}{ Médias $^{(2)}$} & $337,43 \mathrm{~A}$ & $363,05 \mathrm{~A}$ & $345,25 \mathrm{~A}$ & 348,57 \\
\hline & \multicolumn{3}{|c|}{ Zinco das raízes } & \\
\hline $\begin{array}{l}\text { Superior } \\
\text { Mediana }\end{array}$ & $\begin{array}{l}50,04 \mathrm{~B} \mathrm{a} \\
64,22 \mathrm{~B} \mathrm{a}\end{array}$ & $\begin{array}{l}143,45 \mathrm{~A} \mathrm{a} \\
130,32 \mathrm{~A} \mathrm{a}\end{array}$ & $\begin{array}{r}120,45 \mathrm{~A} \mathrm{a} \\
39,67 \mathrm{~B} \mathrm{~b}\end{array}$ & $\begin{array}{r}104,65 \mathrm{~A} \\
78,07 \mathrm{AB}\end{array}$ \\
\hline Inferior & $49,87 \mathrm{~A} \mathrm{a}$ & $66,15 \mathrm{~A} \mathrm{~b}$ & $79,58 \mathrm{~A} \mathrm{ab}$ & $65,20 \mathrm{~B}$ \\
\hline Médias $^{(2)}$ & $54,71 \mathrm{~B}$ & $113,31 \mathrm{~A}$ & $79,90 \mathrm{AB}$ & 82,64 \\
\hline
\end{tabular}

$\left(^{*}\right)$ Valores seguidos por letras iguais não diferem estatísticamente a $5 \%$ pelo teste de Tukey para a comparação entre o fator posição ${ }^{(1)}$ e o fator concentração de cálcio ${ }^{(2)}$. Para a interação concentração de cálcio e posição, letras minúsculas comparam as médias entre as posições dentro de uma mesma concentração de cálcio e letras maiúsculas comparam as médias entre as concentrações de cálcio dentro de uma mesma posição no tubo vertical. 
Tabela 17. Teores médios de nutrientes e sódio nas plantas dos tratamentos 8,55 mmol $\mathrm{L}^{-1}$, em função da posição no tubo vertical. (4 repetições)

\begin{tabular}{ccccccccccccc}
\hline Posição & $\mathrm{N}$ & $\mathrm{P}$ & $\mathrm{K}$ & $\mathrm{Ca}$ & $\mathrm{Mg}$ & $\mathrm{S}$ & $\mathrm{Na}$ & $\mathrm{B}$ & $\mathrm{Cu}$ & $\mathrm{Fe}$ & $\mathrm{Mn}$ & $\mathrm{Zn}$ \\
\hline & \multicolumn{10}{c}{ Parte Aérea } \\
\hline Superior & 34,7 & 6,9 & 74,2 & 21,1 & 5,1 & 5,1 & 1,8 & 42,0 & 48,7 & 1284,3 & 83,6 & 169,4 \\
Mediana & 38,4 & 7,5 & 75,7 & 18,9 & 4,8 & 3,6 & 1,7 & 34,2 & 18,3 & 373,9 & 63,3 & 138,3 \\
Inferior & 37,8 & 7,7 & 78,0 & 18,0 & 4,9 & 3,8 & 1,8 & 46,0 & 19,6 & 413,9 & 59,6 & 144,9 \\
Média & 36,9 & 7,4 & 76,0 & 19,3 & 4,9 & 4,2 & 1,8 & 40,7 & 28,9 & 690,7 & 68,8 & 150,9 \\
\hline \multicolumn{10}{c}{} & \multicolumn{10}{c}{ Raízes } \\
\hline Superior & 35,5 & 11,8 & 45,9 & 8,5 & 2,3 & 3,4 & 3,1 & 36,6 & 74,1 & 6925,8 & 205,3 & 78,8 \\
Mediana & 36,2 & 9,3 & 49,0 & 9,1 & 2,5 & 3,6 & 4,3 & 59,3 & 66,4 & 4661,4 & 138,8 & 89,5 \\
Inferior & 38,8 & 10,6 & 39,8 & 6,6 & 2,2 & 3,2 & 2,6 & 61,7 & 75,6 & 6201,6 & 154,5 & 106,1 \\
Média & 36,8 & 10,6 & 44,9 & 8,1 & 2,3 & 3,4 & 3,3 & 52,5 & 72,0 & 5929,6 & 166,2 & 91,5 \\
\hline
\end{tabular}

Tabela 18. Teores médios de nutrientes e sódio nas plantas dos tratamentos $5,70 \mathrm{mmol}$ $\mathrm{L}^{-1}$, em função da posição no tubo vertical. (4 repetições)

\begin{tabular}{ccccccccccccc}
\hline Posição & $\mathrm{N}$ & $\mathrm{P}$ & $\mathrm{K}$ & $\mathrm{Ca}$ & $\mathrm{Mg}$ & $\mathrm{S}$ & $\mathrm{Na}$ & $\mathrm{B}$ & $\mathrm{Cu}$ & $\mathrm{Fe}$ & $\mathrm{Mn}$ & $\mathrm{Zn}$ \\
\hline & \multicolumn{10}{c}{ Parte Aérea } \\
\hline Superior & 39,2 & 6,7 & 80,0 & 11,3 & 4,7 & 3,2 & 5,4 & 48,6 & 17,6 & 259,2 & 49,8 & 74,4 \\
Mediana & 34,2 & 7,1 & 76,5 & 12,9 & 4,6 & 2,9 & 6,4 & 25,1 & 15,3 & 294,3 & 63,2 & 69,2 \\
Inferior & 35,9 & 7,7 & 75,0 & 12,0 & 4,5 & 3,7 & 5,0 & 35,0 & 23,5 & 294,1 & 44,4 & 76,2 \\
Média & 36,4 & 7,2 & 77,2 & 12,1 & 4,6 & 3,3 & 5,6 & 36,2 & 18,8 & 282,5 & 52,5 & 73,3 \\
\hline \multicolumn{10}{c}{} & \multicolumn{10}{c}{ Raízes } \\
\hline Superior & 38,8 & $\mathbf{8 , 9}$ & 39,8 & 5,6 & 3,1 & 2,9 & 7,9 & 58,1 & 96,0 & 5339,7 & 297,0 & 138,6 \\
Mediana & 36,5 & 9,9 & 44,4 & 4,8 & 2,8 & 3,7 & 6,9 & 70,3 & 91,6 & 6660,6 & 277,6 & 144,4 \\
Inferior & 36,9 & 9,1 & 39,8 & 7,0 & 2,5 & 2,9 & 4,3 & 76,5 & 92,8 & 5686,5 & 269,6 & 129,7 \\
Média & 37,4 & 9,3 & 41,3 & 5,8 & 2,8 & 3,2 & 6,4 & 68,3 & 93,5 & 5895,6 & 281,4 & 137,6 \\
\hline
\end{tabular}

Tabela 19. Teores médios de nutrientes e sódio nas plantas dos tratamentos $2,85 \mathrm{mmol}$ $\mathrm{L}^{-1}$, em função da posição no tubo vertical. (4 repetições)

\begin{tabular}{ccccccccccccc}
\hline Posição & $\mathrm{N}$ & $\mathrm{P}$ & $\mathrm{K}$ & $\mathrm{Ca}$ & $\mathrm{Mg}$ & $\mathrm{S}$ & $\mathrm{Na}$ & $\mathrm{B}$ & $\mathrm{Cu}$ & $\mathrm{Fe}$ & $\mathrm{Mn}$ & $\mathrm{Zn}$ \\
\hline & \multicolumn{10}{c}{ Parte Aérea } \\
\hline Superior & 40,0 & 6,8 & 79,6 & 10,4 & 4,6 & 2,6 & 6,9 & 32,3 & 14,8 & 191,8 & 29,2 & 59,5 \\
Mediana & 36,8 & 6,3 & 82,6 & 11,4 & 4,8 & 2,6 & 6,9 & 23,1 & 14,7 & 203,7 & 44,5 & 72,4 \\
Inferior & 35,6 & 7,9 & 82,6 & 11,7 & 4,8 & 5,1 & 7,4 & 28,5 & 20,7 & 298,1 & 57,7 & 65,2 \\
Média & 37,5 & 7,0 & 81,6 & 11,2 & 4,7 & 3,4 & 7,1 & 28,0 & 16,7 & 231,2 & 43,7 & 65,7 \\
\hline \multicolumn{10}{c}{ Raízes } \\
\hline Superior & 34,4 & 8,2 & 45,9 & 3,9 & 3,4 & 6,2 & 12,0 & 34,4 & 63,8 & 5064,3 & 348,7 & 113,1 \\
Mediana & 34,8 & 9,3 & 44,4 & 3,4 & 3,6 & 6,9 & 13,0 & 62,5 & 59,3 & 4661,4 & 308,8 & 104,4 \\
Inferior & 32,0 & 9,3 & 45,9 & 4,3 & 2,8 & 6,3 & 12,0 & 58,3 & 83,9 & 3825,0 & 314,9 & 100,1 \\
Média & 33,7 & 8,9 & 45,4 & 3,9 & 3,3 & 6,5 & 12,3 & 51,7 & 69,0 & 4517,9 & 324,1 & 105,9 \\
\hline
\end{tabular}




\section{CONCLUSÕES}

A solução nutritiva com menor dose de cálcio $\left(2,85 \mathrm{mmol} \mathrm{L}^{-1}\right)$ e a completa $(5,70$

mmol L $\mathrm{L}^{-1}$ ) foram as mais adequadas, pois resultaram nas maiores produções de alface, cultivar Vera, no sistema de aeroponia.

A solução nutritiva com maior dose de cálcio $\left(8,55 \mathrm{mmol} \mathrm{L}^{-1}\right)$ foi considerada como o tratamento menos indicado para a produção de alface em aeroponia. Esta solução provocou redução na quantidade absorvida dos seguintes nutrientes: $\mathrm{N}, \mathrm{P}, \mathrm{K}$, $\mathrm{Mg}, \mathrm{S}, \mathrm{B}, \mathrm{Cu}, \mathrm{Fe}, \mathrm{Mn}$ e Zn.

A posição superior das plantas nos tubos verticais do sistema de aeroponia resultou nos maiores valores de material fresco e seco e acúmulo de nutrientes, para a cultivar de alface Vera, no sistema de aeroponia.

O sistema de aeroponia apresentou plantas desiguais conforme a posição nos tubos, de baixa qualidade comercial na posição inferior. 


\section{REFERÊNCIAS BIBLIOGRÁFICAS}

ADAMS, C. R. Principles of horticulture . London: Heinemann. 197p. 1984.

ARDITO, S. Ortaggi in coltura aeroponica. Colture Protette, v- 11, p.13-18, 1975.

BRUMM, I.; SCHENK, M. Influence of nitrogen supply on the occurence of calcium deficiency in field grown lettuce. Acta Horticulturae, n. 339, p. 125-136, 1993.

BUENO, C. R. Adubação nitrogenada em cobertura via fertirrigação por gotejamento para a alface americana em ambiente protegido. Lavras, 1998. 54p. Dissertação (Mestrado) -Universidade Federal de Lavras.

CARMELLO, Q. A C.; FURLANI, P.R. Hidroponia : cultivo de plantas sem solo. Piracicaba: ESALQ, 1994. 41 p.

CASTellane, P. D.; ARAÚJO, J. A. C., de. Cultivo sem solo : hidroponia. Jaboticabal: FUNEP, 1994. 43 p.

CASTEllane, P. D.; ARAÚJO, J. A. C., de. Cultivo sem solo - hidroponia. 4 ed., Jaboticabal: FUNEP, 1995. 43 p.

COLLIER, G. F. Tipburn of lettuce. Horticultural Reviews. v. 4, p. 49-65, 1982

COSTA, A. S. V.; SILVA, N. F.; MARTINEZ, H. E. P.; FONTES, P.C.R.; PEREIRA, P. R. G. Utilização de fontes comerciais de fertilizantes no cultivo hidropônico de alface. Revista Ceres, v. 44, p. 169-179, 1997. 
FAQUIN, V.; FURTINI NETO, A. E.; VILELA, L.A.A. Produção de alface em hidroponia,.Lavras: UFLA, 1996. 50p.

FILGUEIRA, F. A. R. Manual de olericultura. São Paulo: Ceres, 1982. 357p.

FURLANI, P. R. Cultivo de alface pela técnica de hidroponia - NFT. Campinas: Instituto Agronômico, 1995. 18p. (IAC. Documentos, 55).

FURLANI, P. R.; SILVEIRA, L.C.P.; BOLONHEZI, D.; FAQUIN, V. Cultivo hidropônico de plantas. Campinas: IAC, 1999. 52p. (IAC Boletim Técnico, 180).

GARCIA, L.C.C. Concentração a acúmulo de micronutrientes em alface (Lactuca sativa L.) cv Brasil 48 e clause's aurélia. Campinas: Fundação Cargill. p. 100-122, 1988.

GARCIA, L.C.C. Deficiência de micronutrientes em alface (Lactuca sativa L.) cv Brasil 48 e clause's aurélia. Campinas: Fundação Cargill. p. 77-100, 1988.

GARCIA, L.C.C. Deficiência de macronutrientes em alface (Lactuca sativa L.) cv Brasil 48 e clause's aurélia. Campinas: Fundação Cargill. p. 123-151, 1988.

GRAVES, C. J. The nutrient film technique.. In: JANICK, J. (Ed.). Horticultural reviews. New York: The AVI Publ,1983. v. 5 , cap. 1, p.1- 44.

JENSEN, M.H. Tomorrow's agriculture today. American Vegetal Growers, v.28,n.3,p.16-19,62,63,1980. 
JONES Jr., J. B. Hydroponics : its history and use in plant nutrition studies. Journal of Plant Nutrition, v. 5 n.8, p. 1003-1030, 1982.

JONES Jr., J. B. A guide for the hydroponic and soilless culture grower. Portland: Timber Press, 1983. 124 p.

KOEFENDER, V. N. Crescimento e absorção de nutrientes pela alface cultivada em fluxo laminar de solução. Piracicaba, 1996. 85p. Dissertação (Mestrado) - Escola Superior de Agricultura "Luiz de Queiroz", Universidade de São Paulo.

LEE, S. K. Aeroponics alternative crop production. Plants, Systems \& Growing Environments, v.1, p.51-55, 1998.

LEE, S.K.; JE, H. Growth and photosynthetic characteristcs of lettuce (Lactuca sativa L.) under fluctuating hot ambient temperatures with the manipulation of cool rootzone temperate. Journal of Plant Physiology, v.152, p.387-391,1998.

MARSCHNER, H. Mineral nutrition of higher plants. London: Academic Press. n.2, 1995. 889p.

MARTINS, C.; RIELLA, M. C. Composição e valor nutritivo dos alimentos. In: RIELLA, M. C. Suporte nutricional parenteral e enteral. 2 ed. Rio de Janeiro: Guanabara Koogan; 1993. p. 416-431.

MASSANTINI, F.L. Aeroponica: realizzazioni pratiche, studi e ricerche. In: INTERNATIONAL CONGRESS ON SOILLESS CULTURE, 3; Sassari, p.83-97 1973. 
OHSE, S. Rendimento, composição centesimal e teores de nitrato e vitamina $\mathrm{C}$ em alface sob hidroponia. Piracicaba, 1999. 117p. Tese (Doutorado) - Escola Superior de Agricultura "Luiz de Queiroz", Universidade de São Paulo

OLIVEIRA, J. E. D. de; MARCHINE, J. S. Ciências nutricionais. São Paulo: Sarvier, 1998. 403p.

RESH, H.M. A definitive guidebook for the advanced home gardener and the commercial hydroponic grower. Hydroponic Food Production,v.50, p.178-187, 1995.

REUTER, D. J.; ROBINSON, J. B. Plant analysis: an interpretation manual. 2. ed. Sydney: Inkata Press, 1997. 572p.

RUSCHEL, J. Acúmulo de nitrato, absorção de nutrientes e produção de duas cultivares de alface cultivadas em hidroponia, em função de doses conjuntas de nitrogênio e potássio. Piracicaba, 1998, 76p. Dissertação (Mestrado) - Escola Superior de Agricultura "Luiz de Queiroz", Universidade de São Paulo

SARRUGE, J.R.; HAAG, H.P. Análises químicas em plantas. Piracicaba, ESALQ, 1974. $56 \mathrm{p}$.

SCHMIDT, D. Cultivares de alface. In: SANTOS, O. S. (Ed.) Hidroponia da alface. Santa Maria: UFSM, 1998. p. 57-62.

SGANZERLA, E. Nova agricultura: a fascinante arte de cultivar com os plásticos. n.5, 1995. 341p. 
SGARBIERI, V. C. Alimentação e nutrição: fator de saúde e desenvolvimento. Campinas: UNICAMP. $1987.387 \mathrm{p}$.

SHIPPERS, P. A. Composition changes in the nutrition solution during the growth of plants in recirculating nutrient culture. In: (SYMPOSIUM ON RESEARCH ON RECIRCULATING WATER CULTURE) 1, Littlehampton, 1979. Acta Horticulturae, n. 98, p. $103-118,1980$.

SOFFER,H.; LEVINGER,D. The Ein Gedi system-research and development of a hydroponic system. In: INTERNATIONAL CONGRESS ON SOILLESS CULTURE, 5. Wageningen, p.241-52, 1980.

THIBODEAU, P. O ; MINOTTI, P. L. The influence of calcium on the development of lettuce tipburn. J. Amer. Soc. Hort. Sci., v. 94, n. 4, p. 372-376, 1969.

VICENZONI, A. Aeroponica: tecnica di coltura senza suolo. Una realizzazione pratica o un progetto sperimentale? Colture Protette, v.4, p.51-59, 1979.

YANAGI, A. A.; BULLOCK, R. M.; CHO, J. J. Factors involved in the development of tipburn in crisphead lettuce in Hawaii. J. Amer. Soc. Hort. Sci., v. 108, n. 2, p. 234237, 1983.

ZITO, R. K.; FRONZA, V.; MARTINEZ, H. E. P.; PEREIRA, P. R. G.; FONTES, P. C. R. Fontes de nutrientes, relações nitrato: amônio e molibdênio, em alface (Lactuca sativa L.) produzida em meio hidropônico. Revista Ceres, v. 41, p. 419-430, 1994. 
ANEXOS 
ANEXO A - Valores de $\mathrm{pH}, \mathrm{CE}$, temperaturas e umidade relativa Max e min durante a fase experimental.

pH $\quad$ CE Tmáx Umáx Tmín Umín

\begin{tabular}{|c|c|c|c|c|c|c|c|c|c|c|}
\hline Dias & S3 & S2 & S1 & S3 & S2 & S1 & & & & \\
\hline $03 / 07 / 00$ & 6,37 & 6,17 & 6,18 & 2,20 & 2,30 & 2,80 & 26,1 & 87 & 13,7 & 49 \\
\hline $04 / 07 / 00$ & 6,62 & 6,66 & 6,64 & 2,30 & 2,30 & 2,70 & 33,7 & 86 & 14,7 & 32 \\
\hline $05 / 07 / 00$ & 6,70 & 6,65 & 6,67 & 2,20 & 2,20 & 2,60 & 35,1 & 76 & 16,3 & 25 \\
\hline $06 / 07 / 00$ & 6,70 & 6,65 & 6,71 & 2,10 & 2,10 & 2,50 & 34,6 & 72 & 16,3 & 27 \\
\hline $07 / 07 / 00$ & 6,50 & 6,50 & 6,60 & 2,00 & 2,10 & 2,50 & 36,4 & 82 & 17,9 & 28 \\
\hline $08 / 07 / 00$ & 6,35 & 6,39 & 6,54 & 2,00 & 2,00 & 2,40 & 36,9 & 73 & 16,6 & 24 \\
\hline $09 / 07 / 00$ & 6,15 & 6,14 & 6,31 & 1,90 & 2,00 & 2,40 & 36,3 & 70 & 9,8 & 23 \\
\hline $10 / 07 / 00$ & 6,04 & 6,03 & 6,20 & 2,00 & 2,10 & 2,30 & 24,7 & 63 & 8,9 & 46 \\
\hline $11 / 07 / 00$ & 5,87 & 5,70 & 5,83 & 2,10 & 2,00 & 2,20 & 26,9 & 66 & 12,3 & 38 \\
\hline $12 / 07 / 00$ & 5,76 & 5,73 & 5,83 & 1,90 & 2,00 & 2,00 & 28,7 & 65 & 15,4 & 30 \\
\hline $13 / 07 / 00$ & 5,62 & 5,57 & 5,80 & 1,80 & 1,90 & 1,90 & 30,8 & 70 & 8,9 & 27 \\
\hline $14 / 07 / 00$ & 5,68 & 5,60 & 5,70 & 1,70 & 1,90 & 1,80 & 26,9 & 83 & 12,6 & 29 \\
\hline $15 / 07 / 00$ & 5,50 & 5,41 & 5,46 & 1,80 & 1,90 & 1,70 & 25,2 & 63 & 14,1 & 21 \\
\hline $16 / 07 / 00$ & 5,38 & 5,23 & 5,32 & 1,60 & 1,80 & 1,60 & 28,3 & 78 & 16,2 & 27 \\
\hline $17 / 07 / 00$ & 5,58 & 5,58 & 5,60 & 2,70 & 2,70 & 3,10 & 26,4 & 62 & 11,3 & 24 \\
\hline $18 / 07 / 00$ & 6,26 & 6,37 & 6,22 & 2,60 & 2,70 & 3,00 & 29,5 & 52 & 10,7 & 33 \\
\hline $19 / 07 / 00$ & 6,16 & 6,26 & 6,27 & 2,50 & 2,70 & 2,70 & 34,2 & 53 & 10,4 & 26 \\
\hline $20 / 07 / 00$ & 6,20 & 6,14 & 6,14 & 2,40 & 2,60 & 2,60 & 36,1 & 65 & 11,6 & 16 \\
\hline $21 / 07 / 00$ & 6,00 & 5,82 & 5,85 & 2,30 & 2,50 & 2,50 & 23,0 & 66 & 12,5 & 15 \\
\hline $22 / 07 / 00$ & 5,90 & 5,79 & 6,15 & 2,20 & 2,40 & 2,40 & 28,7 & 62 & 14,1 & 26 \\
\hline $23 / 07 / 00$ & 6,08 & 5,82 & 6,00 & 2,10 & 2,30 & 2,30 & 28,5 & 63 & 14,4 & 16 \\
\hline $24 / 07 / 00$ & 5,66 & 6,00 & 6,13 & 2,00 & 2,20 & 2,10 & 30,2 & 68 & 15,9 & 15 \\
\hline $25 / 07 / 00$ & 5,50 & 5,65 & 6,12 & 1,90 & 2,10 & 2,00 & 32,0 & 64 & 14,7 & 32 \\
\hline $26 / 07 / 00$ & 5,58 & 5,75 & 5,89 & 1,80 & 1,90 & 1,90 & 33,6 & 65 & 13,5 & 31 \\
\hline $27 / 07 / 00$ & 6,13 & 5,88 & 6,00 & 1,70 & 1,70 & 1,70 & 34,9 & 62 & 16,3 & 34 \\
\hline $28 / 07 / 00$ & 6,49 & 6,11 & 6,12 & 1,60 & 1,60 & 1,60 & 35,5 & 45 & 15,5 & 23 \\
\hline $29 / 07 / 00$ & 6,82 & 6,42 & 6,54 & 1,50 & 1,50 & 1,50 & 34,2 & 49 & 15,7 & 24 \\
\hline $30 / 07 / 00$ & 6,66 & 6,56 & 6,31 & 2,50 & 2,60 & 3,00 & 29,3 & 48 & 15,7 & 16 \\
\hline $31 / 07 / 00$ & 6,53 & 6,39 & 6,18 & 2,40 & 2,50 & 2,70 & 32,3 & 43 & 18,6 & 14 \\
\hline $01 / 08 / 00$ & 6,33 & 6,27 & 5,64 & 2,30 & 2,40 & 2,50 & 23,5 & 56 & 9,4 & 13 \\
\hline $02 / 08 / 00$ & 5,64 & 5,59 & 5,40 & 2,20 & 2,30 & 2,40 & 29,2 & 57 & 10,3 & 23 \\
\hline $03 / 08 / 00$ & 5,56 & 5,48 & 5,16 & 1,80 & 2,00 & 2,20 & 32,3 & 68 & 17,5 & 20 \\
\hline $04 / 08 / 00$ & 5,48 & 5,30 & 5,30 & 1,70 & 1,90 & 2,00 & 35,0 & 35 & 13,6 & 32 \\
\hline $05 / 08 / 00$ & 6,00 & 5,50 & 5,30 & 1,60 & 1,80 & 1,90 & 37,0 & 68 & 15,4 & 35 \\
\hline $06 / 08 / 00$ & 6,31 & 5,60 & 6,00 & 1,50 & 1,70 & 1,80 & 37,4 & 65 & 16,2 & 25 \\
\hline $07 / 08 / 00$ & 6,17 & 6,25 & 6,16 & 1,40 & 1,50 & 1,50 & 29,7 & 62 & 15,7 & 33 \\
\hline $08 / 08 / 00$ & 6,52 & 6,44 & 5,47 & 2,30 & 2,40 & 2,70 & 32,9 & 63 & 14,6 & 35 \\
\hline $09 / 08 / 00$ & 5,78 & 6,15 & 6,35 & 2,20 & 2,30 & 2,50 & 30,2 & 74 & 10,6 & 28 \\
\hline
\end{tabular}


ANEXO B - Resumo da Análise de variância para as características avaliadas

\section{Material Fresco Paérea}

Causas Da Variação

G.L

Q.M

Solu

2

681,59

Prob. $>$ F

Reps

Residuo (A)

Parcelas

Posi

Sol*Pos

3

6

11

2

462,63

441,91

0,1023

Residuo (B)

Subparcelas

Media Geral $=74,73$

Coeficiente de Variação $(A)=28,78 \%$

Coeficiente de Variação $(B)=17,52 \%$

Dms A 5\% para comparação de médias entre concentrações de cálcio - 26,95

Dms A 5\% para comparação de médias entre posições - 13,65

Dms A 5\% para comparação de médias entre concentrações de cálcio dentro de posiçōes $-30,07$

Dms A 5\% para comparação de médias entre posições dentro de concentrações de cálcio - 23,64

Material Fresco Raizes

Causas Da Variação

G.L

Solu

Reps

Residuo (A)

Parcelas

Posi

Sol*Pos

Residuo (B)

Subparcelas

Media Geral $=12,08$

Coeficiente de Variação $(A)=48,35 \%$

Coeficiente de Variação (B) $=37,12 \%$

Dms A 5\% para comparação de médias entre concentrações de cálcio-7,32

Dms A 5\% para comparação de médias entre posições $-4,67$

Dms A 5\% para comparação de médias entre concentraç̋̃es de cálcio dentro de posiç̋es $-8,94$

Dms A 5\% para comparação de médias entre posições dentro de concentraçð̃es de cálcio $-8,10$

Material Seco Paćrea

Causas Da Variação

G.L

Solu

2

Reps

Residuo (A)

Parcelas

Posi

$\mathrm{Sol}^{*} \mathrm{Pos}$

Residuo (B)

Subparcelas

Media Geral $=\quad 2,47$

Coeficiente de Variação $(A)=36,13 \%$

Coeficiente de Variação (B) $=29,44 \%$

Dms A 5\% para comparação de médias entre concentrações de cálcio - 1,12

Dms A 5\% para comparação de médias entre posições $-0,76$
Q.M

4,34

34,12

30,34

$65,700,0349$

20,12
Prob.>F

0,8823

0,2473
Prob.>F

0,1588

2,00

0,79

2,93

$1,250,0895$

0,53 


\section{Material Seco Raizes}

\section{Causas Da Variação}

Solu

G.L

2

Reps

Residuo (A)

Parcelas

Posi

$\mathrm{Sol}^{*} \mathrm{Pos}$

Residuo (B)

Subparcelas

Media Geral $=0,72$

Coeficiente de Variação $(A)=43,92 \%$

Coeficiente de Variação (B) $=37,35 \%$

Dms A 5\% para comparação de médias entre concentrações de cálcio-0,40

Dms A 5\% para comparação de médias entre posições - 0,28

Dms A 5\% para comparação de médias entre concentrações de cálcio dentro de posições $-0,52$

Dms A 5\% para comparação de médias entre posiç̃es dentro de concentrações de cálcio - 0,49

Porcentagem de Material Seco Paérea

Causas Da Variação

G.L

Solu

Reps

Residuo (A)

Parcelas

Posi

Sol*Pos

Residuo (B)

Subparcelas

Media Geral $=3,22$

Coeficiente de Variação $(A)=15,53 \%$

Coeficiente de Variação $(B)=19,51 \%$

Dms A $5 \%$ para comparação de médias entre concentrações de cálcio-0,63

Dms A $5 \%$ para comparação de médias entre posiç̃es $-0,65$

Porcentagem de Material Seco Raízes

Causas Da Variação

Solu

\section{G.L}

2

Reps

Residuo (A)

Parcelas

Posi

Sol*Pos

Residuo (B)

Subparcelas

Media Geral :

Coeficiente de Variação $(A)=22,88 \%$

Coeficiente de Variação $(B)=19,92 \%$

Dms A 5\% para comparação de médias entre concentrações de cálcio - 1,76

Dms A $5 \%$ para comparação de médias entre posições $-1,28$
Q.M

0,14

Prob. $>$ F

0,3403

0,10

0,34

$0,25 \quad 0,0293$

0,07

0,0237
Prob.>F

0,0493

0,25

2,27

$0,190,7490$

0,39

0,0116
Prob.>F

0,0112

1,98

7,57

$2,19 \quad 0,2548$

1,50

0,0180 


\section{Relação Parte aérea/Raiz}

\begin{tabular}{|c|c|c|c|}
\hline Causas Da Variação & G.L & Q.M & Prob. $>$ F \\
\hline Solu & 2 & 3,10 & 0,6798 \\
\hline Reps & 3 & & \\
\hline Residuo (A) & 6 & 7,43 & \\
\hline Parcelas & 11 & & \\
\hline Posi & 2 & 0,11 & 0,9814 \\
\hline Sol*Pos & 4 & $6,44 \quad 0,3769$ & \\
\hline Residuo (B) & 18 & 5,73 & \\
\hline Subparcelas & 35 & & \\
\hline Media Geral $=4,08$ & & & \\
\hline Coeficiente de Variaç & $\%$ & & \\
\hline Coeficiente de Variaç & & & \\
\hline Dms A $5 \%$ para comp & as entr & Icio-3,42 & \\
\hline Dms A $5 \%$ para comp & as entr & & \\
\hline Nitrogênio Paérea & & & \\
\hline Causas Da Variação & G.L & Q.M & Prob. $>F$ \\
\hline Solu & 2 & 3373,01 & 0,1105 \\
\hline Reps & 3 & & \\
\hline Residuo (A) & 6 & 1038,38 & \\
\hline Parcelas & 11 & & \\
\hline Posi & 2 & 2184,16 & 0,0694 \\
\hline $\mathrm{Sol}^{*} \mathrm{P}$ os & 4 & 2318,31 & 0,0347 \\
\hline Residuo (B) & 18 & 709,07 & \\
\hline Subparcelas & 35 & & \\
\hline Media Geral $=88,8$ & & & \\
\hline Coeficiente de Variaç & $5 \%$ & & \\
\hline Coeficiente de Variaç & & & \\
\hline Dms A $5 \%$ para comp & as entr & Icio $-40,37$ & \\
\hline Dms A 5\% para comp & las entr & & \\
\hline Dms A $5 \%$ para comp & las entr & álcio dentro de posi & \\
\hline Dms A 5\% para comp & las entr & concentrações de ce & \\
\hline Nitrogênio Raízes & & & \\
\hline Causas Da Variação & G.L & Q.M & Prob.$>F$ \\
\hline Solu & 2 & 217,71 & 0,2475 \\
\hline Reps & 3 & & \\
\hline Residuo (A) & 6 & 122,52 & \\
\hline Parcelas & 11 & & \\
\hline Posi & 2 & 487,47 & 0,0174 \\
\hline Sol*Pos & 4 & 296,76 & 0,0415 \\
\hline Residuo (B) & 18 & 95,85 & \\
\hline Subparcelas & 35 & & \\
\hline Media Geral $=25,9$ & & & \\
\hline Coeficiente de Variaç & $1 \%$ & & \\
\hline Coeficiente de Variac & $8 \%$ & & \\
\hline Dms A 5\% para comp & las entr & Icio $-13,87$ & \\
\hline Dms A $5 \%$ para comp & as entr & & \\
\hline Dms A 5\% para comp & as entr & io dentro de po & \\
\hline Dms A $5 \%$ para comp & & centracões d & \\
\hline
\end{tabular}




\section{Fósforo Paérea}

Causas Da Variação

Solu

$$
\text { G.L }
$$

Reps

Residuo (A)

Parcelas

Posi

Sol*Pos

Residuo (B)

Subparcelas

Media Geral

Coeficiente de Variação $(A)=34,40 \%$

Coeficiente de Variação (B) $=29,04 \%$

Dms A 5\% para comparação de médias entre concentrações de cálcio - 7,55

Dms A 5\% para comparação de médias entre posições $-5,30$

Fósforo Raízes

Causas Da Variação

G.L

Solu

2

Reps

Residuo (A)

Parcelas

Posi

Sol ${ }^{*}$ Pos

Residuo (B)

Subparcelas

Media Geral $=6,84$

Coeficiente de Variação $(A)=41,66 \%$

Coeficiente de Variação $(B)=36,15 \%$

Dms A 5\% para comparação de médias entre concentraç̃̃es de cálcio-3,57

Dms A $5 \%$ para comparação de médias entre posiç̋̃es $-2,58$

Dms A $5 \%$ para comparação de médias entre concentrações de cálcio dentro de posições $-4,65$

Dms A 5\% para comparação de médias entre posições dentro de concentrações de cálcio $-4,47$

Potássio Paérea

Causas Da Variação

Solu

G.L

Reps

Residuo (A)

Parcelas

Posi

$\mathrm{Sol}^{*} \mathrm{P} \propto \mathrm{s}$

Residuo (B)

Subparcelas

Media Geral =

Coeficiente de Variação $(A)=36,67 \%$

Coeficiente de Variação $(B)=29,48 \%$

Dms A $5 \%$ para comparação de médias entre concentrações de cálcio - 86,51

Dms A $5 \%$ para comparação de médias entre posições $-57,84$

Dms A $5 \%$ para comparação de médias entre concentrações de cálcio dentro de posiçð̃es $-108,03$

Dms A 5\% para comparação de médias entre posições dentro de concentrações de cálcio - 100,17
Q.M

11614,38

4767,61

15075,27

9013,37

3080,05
Prob. $>$ F

0,5292

0,1051
Prob. $>$ F

0,5467

0,0286
Prob.>F

0,1678

0,0197

0,0496 


\section{Potássio Raízes}

Prob. $>\mathrm{F}$

Causas Da Variação

Q.M

Solu

G.L

2

Reps

Residuo (A)

Parcelas

Posi

Sol*Pos

Residuo (B)

Subparcelas

Media Geral $=31,86$

Coeficiente de Variação $(A)=46,74 \%$

Coeficiente de Variação $(B)=37,19 \%$

Dms A 5\% para comparação de médias entre concentrações de cálcio-18,66

Dms A $5 \%$ para comparação de médias entre posições - 12,35

Dms A 5\% para comparação de médias entre concentrações de cálcio dentro de posições $-23,17$

Dms A 5\% para comparação de médias entre posições dentro de concentrações de cálcio - 21,38

Cálcio Paérea

Causas Da Variação

Solu

Reps

Residuo (A)

Parcelas

Posi

Sol*Pos

Residuo (B)

Subparcelas

Media Geral $=36,94$

Coeficiente de Variação $(A)=28,04 \%$

Coeficiente de Variação (B) $=27,80 \%$

Dms A 5\% para comparação de médias entre concentrações de cálcio - 12,98

Dms A 5\% para comparação de médias entre posições $-10,70$

\section{Cálcio Raizes}

Causas Da Variação

Solu

G.L

Reps

Residuo (A)

Parcelas

Posi

Sol ${ }^{*}$ Pos

Residuo (B)

Subparcelas

Media Geral $=4,16$

Coeficiente de Variação $(A)=44,65 \%$

Coeficiente de Variação $(B)=39,12 \%$

Dms A $5 \%$ para comparação de médias entre concentrações de cálcio-2,32

Dms A 5\% para comparação de médias entre posições $-1,70$

Dms A 5\% para comparação de médias entre concentrações de cálcio dentro de posições $-3,05$

Dms A $5 \%$ para comparação de médias entre posições dentro de concentrações de cálcio - 2,94
Q.M

13,93

3,45

8,92

$8,51 \quad 0,0370$

2,65
0,5287

0,0233

0,0123

Prob.>F

0,1240

0,0024

0,1198

Prob.>F

0,0771

0,0563 


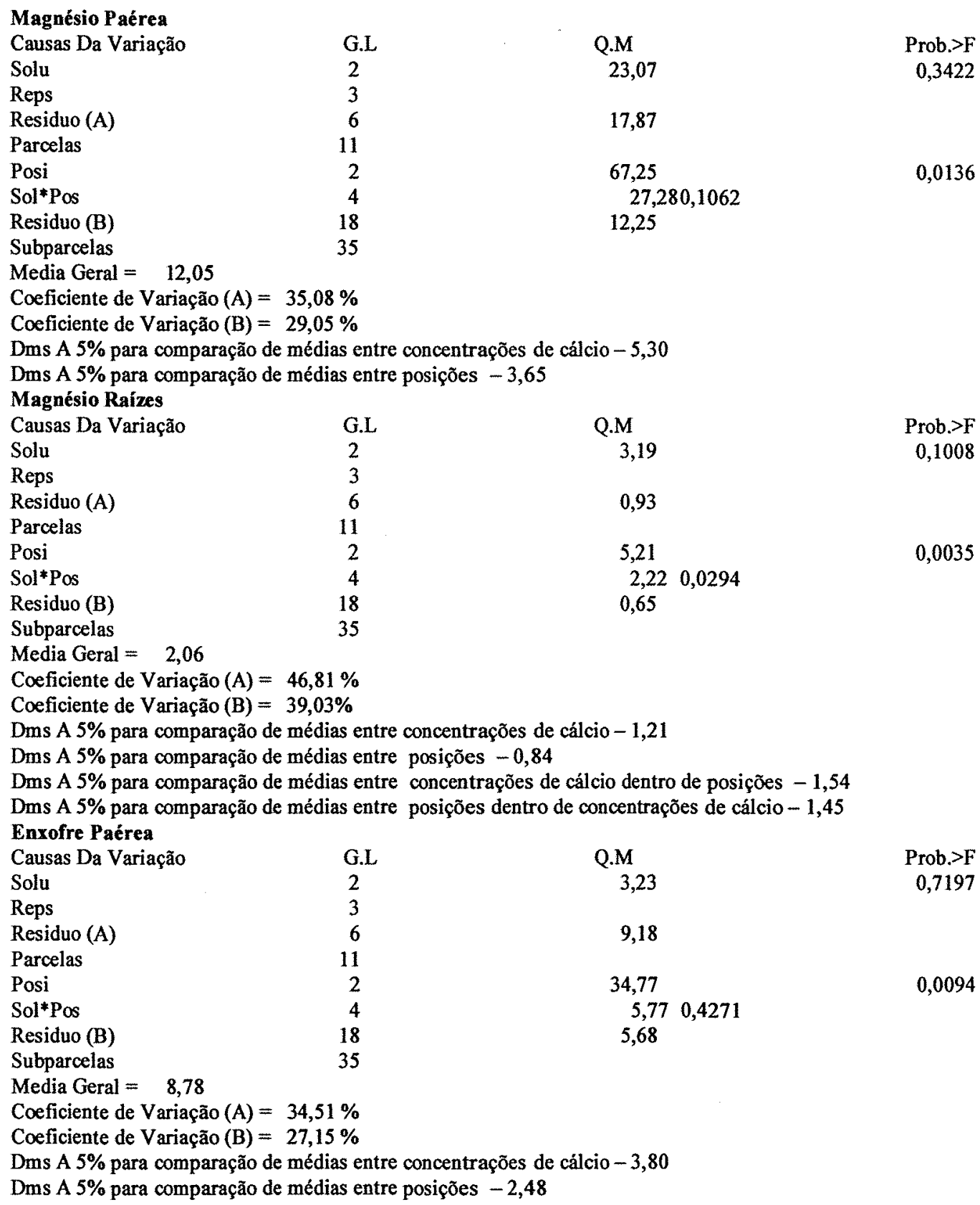




\section{Enxofre Raizes}

Causas Da Variação

Solu

G.L

2

Reps

Residuo (A)

Parcelas

Posi

Sol*Pos

Residuo (B)

Subparcelas

Media Geral

Coeficiente de Variação $(\mathrm{A})=58,28 \%$

Coeficiente de Variação $(B)=39,18 \%$

Dms A 5\% para comparação de médias entre concentrações de cálcio-2,30

Dms A $5 \%$ para comparação de médias entre posições - 1,28

Dms A $5 \%$ para comparação de médias entre concentrações de cál cio dentro de posiçð̃es $-2,65$

Dms A $5 \%$ para comparação de médias entre posições dentro de concentrações de cálcio - 2,22

Sódio Paérea

Causas Da Variação

Solu

Reps

Residuo (A)

Parcelas

Posi

Sol*Pos

Residuo (B)

Subparcelas

Media Geral $=9,97$

Coeficiente de Variação $(A)=78,86 \%$

Coeficiente de Variação $(B)=32,89 \%$

Dms A 5\% para comparação de médias entre concentraç̃̃es de cálcio-9,85

Dms A $5 \%$ para comparação de médias entre posições $-3,42$

Dms A $5 \%$ para comparação de médias entre concentrações de cálcio dentro de posiçōes $-10,22$

Dms A $5 \%$ para comparação de médias entre posições dentro de concentrações de cálcio $-5,92$

Sódio Raízes

Causas Da Variação

Solu

Reps

Residuo (A)

Parcelas

Posi

Sol*Pos

Residuo (B)

Subparcelas

Media Geral $=5,57$

Coeficiente de Variação $(A)=61,12 \%$

Coeficiente de Variação $(B)=42,61 \%$

Dms A 5\% para comparação de médias entre concentrações de cálcio-4,26

Dms A $5 \%$ para comparação de médias entre posições $-2,47$

Dms A $5 \%$ para comparação de médias entre concentrações de cálcio dentro de posiçōes $-5,01$

Dms A 5\% para comparação de médias entre posições dentro de concentrações de cálcio $-4,28$
Prob. $>$ F

0,0481

Prob. $>\mathrm{F}$

0,0039

0,0034
Prob. $>\mathrm{F}$ 0,0077

11,59

38,97

$31,850,0042$

5,63 
Boro Paérea

Causas Da Variação

G.L

2

Solu

Reps

Residuo (A)

Parcelas

Posi

$\mathrm{Sol}^{*} \mathrm{Pos}$

Residuo (B)

Subparcelas

Media Geral

Coeficiente de Variação $(\mathrm{A})=32,38 \%$

Coeficiente de Variação (B) $=32,74 \%$

Dms A 5\% para comparação de médias entre concentrações de cálcio-38,58

Dms A $5 \%$ para comparação de médias entre posições $-32,44$

Dms A 5\% para comparação de médias entre concentraçð̃es de cálcio dentro de posições $-54,94$

Dms A 5\% para comparação de médias entre posições dentro de concentrações de cálcio - 56,20

Boro Raizes

Causas Da Variação

Solu

Reps

Residuo (A)

Parcelas

Posi

Sol*Pos

Residuo (B)

Subparcelas

Media Geral $=40,46$

Cœeficiente de Variação $(A)=41,05 \%$

Coeficiente de Variação $(B)=37,88 \%$

Dms A 5\% para comparação de médias entre concentrações de cálcio-20,81

Dms A 5\% para comparação de médias entre posições - 15,97

Dms A 5\% para comparação de médias entre concentrações de cálcio dentro de posições $-28,02$

Dms A $5 \%$ para comparação de médias entre posições dentro de concentrações de cálcio $-27,66$

\section{Cobre Paérea}

Causas Da Variação

Solu

G.L

2

Reps

Residuo (A)

Parcelas

Posi

Sol*Pos

Residuo (B)

Subparcelas

Media Geral $=46,17$

Coeficiente de Variação $(A)=36,28 \%$

Coeficiente de Variação (B) $=28,97 \%$

Dms A 5\% para comparação de médias entre concentrações de cálcio-20,98

Dms A $5 \%$ para comparação de médias entre posições $-13,94$

234,82
Prob. $>$ F

0,0974

0,0016

0,0020

Prob. $>$ F

0,0334

0,7181

0,0352
Prob.>F

0,5283

280,51

670,33

345,67

178,88
0,0426

0,1482 
Cobre Raizes

\begin{tabular}{|c|c|c|c|}
\hline Causas Da Variação & G.L & Q.M & Prob. $>F$ \\
\hline Solu & 2 & 3290,09 & 0,0602 \\
\hline Reps & 3 & & \\
\hline Residuo (A) & 6 & 707,63 & \\
\hline Parcelas & 11 & & \\
\hline Posi & 2 & 1340,17 & 0,1063 \\
\hline Sol*Pos & 4 & 3108,38 & 0,0036 \\
\hline Residuo (B) & 18 & 530,11 & \\
\hline Subparcelas & 35 & & \\
\hline \multicolumn{4}{|c|}{ Media Geral $=59,84$} \\
\hline \multicolumn{4}{|c|}{ Coeficiente de Variação $(A)=44,45 \%$} \\
\hline \multicolumn{4}{|c|}{ Coeficiente de Variação $(B)=38,48 \%$} \\
\hline \multicolumn{4}{|c|}{ Dms A 5\% para comparação de médias entre concentrações de cálcio - 33,33 } \\
\hline \multicolumn{4}{|c|}{ Dms A $5 \%$ para comparação de médias entre posições $-23,99$} \\
\hline \multicolumn{4}{|c|}{ Dms A $5 \%$ para comparação de médias entre concentrações de cálcio dentro de posições $-43,30$} \\
\hline \multicolumn{4}{|c|}{ Dms A $5 \%$ para comparação de médias entre posições dentro de concentrações de cálcio $-41,56$} \\
\hline \multicolumn{4}{|c|}{ Ferro Paérea } \\
\hline Causas Da Variação & G.L & Q.M & Prob. $>$ F \\
\hline Solu & 2 & 216907,97 & 0,2153 \\
\hline Reps & 3 & & \\
\hline Residuo (A) & 6 & 108294,98 & \\
\hline Parcelas & 11 & & \\
\hline Posi & 2 & 878056,66 & 0,0009 \\
\hline Sol*Pos & 4 & 316679,98 & 0,0149 \\
\hline Residuo (B) & 18 & 76425,03 & \\
\hline Subparcelas & 35 & & \\
\hline
\end{tabular}

Media Geral $=929,71$

Coeficiente de Variação $(A)=35,40 \%$

Coeficiente de Variação $(B)=29,74 \%$

Dms A 5\% para comparação de médias entre concentrações de cálcio-412,29

Dms A $5 \%$ para comparação de médias entre posições $-288,09$

Dms A 5\% para comparação de médias entre concentrações de cálcio dentro de posições $-528,12$

Dms A 5\% para comparação de médias entre posições dentro de concentrações de cálcio $-499,00$

Ferro Raízes

Causas Da Variação $\quad$ G.L
Solu

Solu

Reps

Residuo (A)

Parcelas

Posi

Sol*Pos

Residuo (B)

Subparcelas

Media Geral $=3922,31$

Coeficiente de Variação $(A)=39,01 \%$

Coeficiente de Variação $(B)=36,65 \%$

Dms A 5\% para comparação de Médias entre concentrações de cálcio - 1917,1

Dms A 5\% para comparação de Médias entre posições - 1498,13

Dms A 5\% para comparação de médias entre concentrações de cálcio dentro de posições $-2611,33$

Dms A 5\% para comparação de médias entre posições dentro de concentrações de cálcio - 2594,84
Prob. $>$ F

0,1201

2341493,93

14329419,50

6359392,90

0,0060

0,0423 


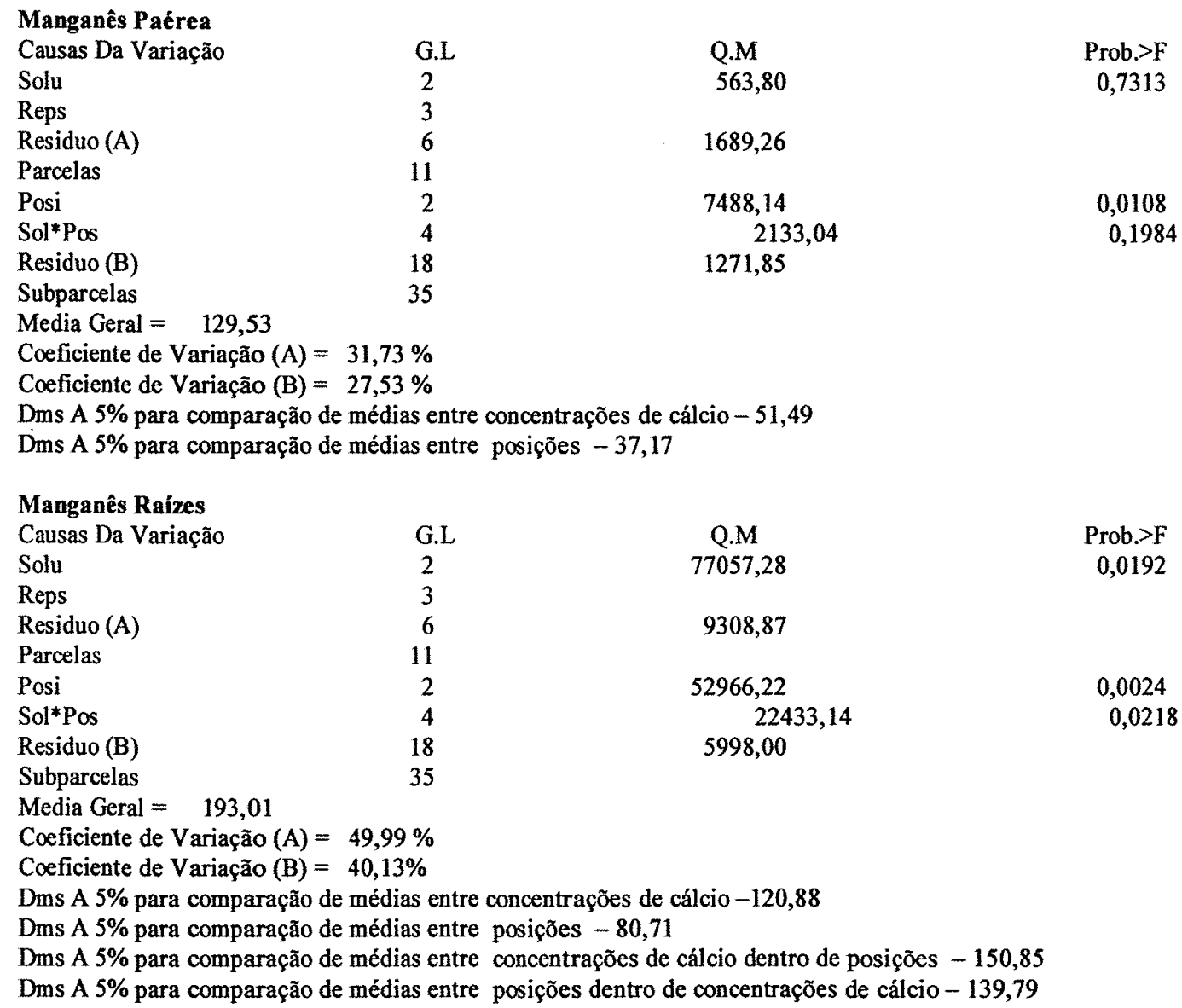




\section{Zinco Paérea}

Causas Da Variação

Solu

Reps

Residuo (A)

Parcelas

Posi

Sol ${ }^{* P o s}$

Residuo (B)

Subparcelas

Media Geral $=348,57$

Coeficiente de Variação $(A)=31,20 \%$

Coeficiente de Variação $(B)=29,37 \%$

Dms A 5\% para comparação de médias entre concentrações de cálcio - 136,23

Dms A 5\% para comparação de médias entre posições - 106,69

\section{Zinco Raízes}

Causas Da Variação

G.L

Solu

2

Reps

Residuo (A)

Parcelas

Posi

$\mathrm{Sol}^{*} \mathrm{Pos}$

Residuo (B)

Subparcelas

Media Geral =

Coeficiente de Variação $(\mathrm{A})=42,46 \%$

Coeficiente de Variação $(B)=38,70 \%$

Dms A 5\% para comparação de médias entre concentrações de cálcio - 43,96

Dms A 5\% para comparação de médias entre posições - 33,33

Dms A 5\% para comparação de médias entre concentrações de cálcio dentro de posiçð̃es $-58,75$

Dms A 5\% para comparação de médias entre posições dentro de concentrações de cálcio - 57,73
1231,36

4856,61

4392,36

1022,86

2068,42

13845,42

10480,85

Q.M

(1)
Prob.>F

0,8436

0,0000

0,2997

Prob. $>$ F

0,0186

0,0216

0,0129 